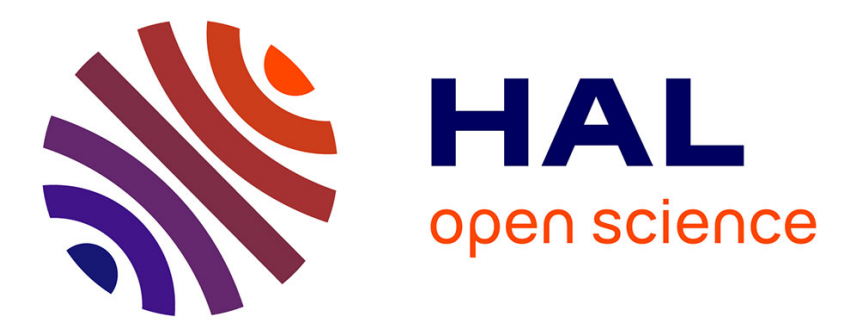

\title{
Potential of CO2 capture from flue gases by physicochemical and biological methods: A comparative study
}

Ismael Matito-Martos, Claudia Sepúlveda, Cintia Gómez, Gabriel Acién, Julio Perez-Carbajo, José Delgado, V.I. Águeda, Conchi Maria Concepcion Ovin Ania, José Parra, Sofía Calero, et al.

\section{To cite this version:}

Ismael Matito-Martos, Claudia Sepúlveda, Cintia Gómez, Gabriel Acién, Julio Perez-Carbajo, et al.. Potential of $\mathrm{CO} 2$ capture from flue gases by physicochemical and biological methods: A comparative study. Chemical Engineering Journal, 2021, 417, pp.128020. 10.1016/j.cej.2020.128020 . hal03433527

\section{HAL Id: hal-03433527 https://hal.science/hal-03433527}

Submitted on 18 Nov 2021

HAL is a multi-disciplinary open access archive for the deposit and dissemination of scientific research documents, whether they are published or not. The documents may come from teaching and research institutions in France or abroad, or from public or private research centers.
L'archive ouverte pluridisciplinaire HAL, est destinée au dépôt et à la diffusion de documents scientifiques de niveau recherche, publiés ou non, émanant des établissements d'enseignement et de recherche français ou étrangers, des laboratoires publics ou privés. 


\section{Potential of $\mathrm{CO}_{2}$ capture from flue gases by physicochemical and biological methods: a comparative study}

Doi: $\langle 10.1016 /$ j.cej.2020.128020 $\rangle$

Ismael Matito-Martos, ${ }^{\mathrm{a}, \mathscr{I}}$, Claudia Sepulveda ${ }^{\mathrm{b}, \mathbb{I}, *}$, Cintia Gómez ${ }^{\mathrm{c}}$, Gabriel Acién ${ }^{\mathrm{c}}$, Julio Perez-Carbajo $^{a}$, J. A. Delgado ${ }^{\text {d }}$, V. I. Águeda ${ }^{\mathrm{d}}$, Conchi Ania ${ }^{\mathrm{e}}$, J. B. Parra ${ }^{f}$, S. Calero ${ }^{\mathrm{a}}$ and J. A. Anta ${ }^{\mathrm{a}}$

II These two authors contributed equally to this work.

${ }^{a}$ Department of Physical, Chemical and Natural Systems, University Pablo de Olavide, Sevilla 41013, Spain

${ }^{\mathrm{b}}$ Bio-innovation Centre, Antofagasta Institute, University of Antofagasta, Chile

${ }^{c}$ Department of Chemical Engineering, University of Almería, 04120 Almería, Spain

${ }^{d}$ Department of Chemical Engineering, Universidad Complutense de Madrid, 28040, Madrid, Spain

${ }^{e}$ CEMTHI (CNRS UPR 3079) Université d'Orléans, 45071, Orléans, France.

${ }^{f}$ Instituto Nacional del Carbón, INCAR, CSIC, P.O. 73, 33080 Oviedo, Spain.

Corresponding authors*: Claudia Sepúlveda (Claudia.sepulveda@uantof.cl), Juan A. anta (anta@upo.es)

KEYWORDS: $\mathrm{CO}_{2}$ capture, zeolites, microalgae, light efficiency 


\begin{abstract}
The industrial viability of state-of-the art technologies for $\mathrm{CO}_{2}$ capture from flue gases and their commercial valorization is analysed and compared. Our focus is on the alternative capabilities of physicochemical and biological methods, i.e., adsorption in porous commercial zeolites and biomass production by microalgae, respectively. In both cases the study is organized in two steps: first the best system for $\mathrm{CO}_{2}$ capture is selected (type of zeolite in one case and microalgae strain in the other). Second figures about their performance at real conditions are obtained and the advantages and disadvantages of each alternative are discussed. For the physicochemical process, it is found that commercial zeolite MFI is the best choice for $\mathrm{CO}_{2}$ capture from a typical industrial flue gas emission. Numerical simulations of dual PSA cycle at ambient conditions (pressure and temperature) provides a value of $8 \mathrm{~kg} \mathrm{~m}^{-3}$ bed $\mathrm{h}^{-1}$ and an energy compsuption of $0.987 \mathrm{MJ} / \mathrm{Kg}$ of captured $\mathrm{CO}_{2}$. As regards the biological process, evaluation of different microalgae strains in continuous mode using low cost resources (low quality water, fertilizers, flue gases), results in Scenedesmus as the most promising strain. The maximal capacity of $\mathrm{CO}_{2}$ capture determined at laboratory conditions was $0.1 \mathrm{~kg} \mathrm{~m}^{-3}$ broth $\mathrm{h}^{-1}$, allowing to produce up to 0.06 of $\mathrm{kg} \mathrm{m}^{-3}$ broth $\mathrm{h}^{-1}$ of biomass with a $3 \%$ maximal photosynthetic efficiency. Although this is a significantly lower value, the produced biomass is mainly composed by carbohydrates, that would lead to an overall economic yield being $0.6 € / \mathrm{m}^{3}$. day. These figures allow to confirm the reliability of the process at large scale. To demonstrate it, experiments were performed in a $100 \mathrm{~m}^{2}$ pilot scale raceway reactor under real outdoor conditions. At these conditions the $\mathrm{CO}_{2}$ capture capacity was $54 \mathrm{~g} / \mathrm{m}^{2}$. day (equivalent to $197 \mathrm{tn} /$ ha year) with biomass productivity values of $21 \mathrm{~g} / \mathrm{m}^{2} \cdot$ day (equivalent to 75 tn/ha· year) on an annual basis. On the other hand, the energy consumption approaches to $0.48 \mathrm{MJ} / \mathrm{kgCO}_{2}$, lower than amines-related absorption process, of $4 \mathrm{MJ} / \mathrm{kgCO}_{2}$, and zeolites adsorption.
\end{abstract}




\section{INTRODUCTION}

The relationship between Global Warming and increasing emissions of Green House Gases (GHG) is not more under discussion, most of the countries signing the Paris Protocol to mitigate the anthropogenic emissions of these gases. ${ }^{1}$ Thus, countries are enforced to implement real mitigation strategies considering reduction of GHG emission both by improvement of the technology for energy production and the development of technologies for GHG capture. Among the different GHG, carbon dioxide is one of the most relevant for the larger magnitude of its emission, mainly related with energy production for fossil fuels ${ }^{2}$. A reduction in power consumption or improvements to combustion processes can help reducing $\mathrm{CO}_{2}$ emissions. Alternatively, carbon capture and storage (CCS) shows great potential in diminishing the amount of $\mathrm{CO}_{2}$ released into the atmosphere from industrial and civil combustion processes ${ }^{3,4}$. CCS refers to strategies for capturing $\mathrm{CO}_{2}$ from flue gases followed by long-term storage for hundreds of years; these are capable of contributing up to $55 \%$ to the mitigation effort ${ }^{3}$. Different technologies have been proposed for $\mathrm{CO}_{2}$ capture, ${ }^{5}$ the most conventional being based on ammines-related absorption processes, ${ }^{6}$ other using membranes ${ }^{7}$ or including cryogenic processes ${ }^{8}$ to capture the $\mathrm{CO}_{2}$ from the flue gases. A major problem related with these technologies is the large energy consumption, the difficulty to recover the $\mathrm{CO}_{2}$ gas, and its tolerance to the corrosive conditions imposed by the flue gases composition ${ }^{9}$. Additionally, the utilization of porous materials for $\mathrm{CO}_{2}$ adsorption in Pressure Switch Adsorption (PSA) processes has been also proposed. ${ }^{10}$ This technology requires less energy and also facilitates the recovery of the $\mathrm{CO}_{2}$ gas by using a readily available driving force such as the pressure difference between the high feed pressure for adsorption and a lower pressure for desorption. However, PSA methods still rely on the availability of materials with improved properties in terms of $\mathrm{CO}_{2}$ adsorption capacity and selectivity. Materials that have been thoroughly studied are mainly inorganic zeolites, ${ }^{11}$ metal organic frameworks ${ }^{12}$, as well as the functionalization of these with room temperature ionic liquids ${ }^{13}$ among others. It must be born in mind that whatever the $\mathrm{CO}_{2}$ capture process is, energy consumption must remain low and, besides, the final product, in the form of a concentrated $\mathrm{CO}_{2}$ stream, must be valorised. 
As an alternative to chemical and physicochemical techniques, the utilization of microalgae for $\mathrm{CO}_{2}$ capture process has also been proposed. This biological process has been reported to require less energy, thus it is potentially more sustainable from the environmental point of view. However, biological methods are more sensible to pollutants contained into the flue gases and their typical rate of $\mathrm{CO}_{2}$ capture is lower than that of chemical processes. ${ }^{14,15}$ In spite of that, they have the critical advantage of providing a final product (microalgae biomass) that would be more valuable than the $\mathrm{CO}_{2}$ stream of the chemical and physicochemical methods, thus positively contributing to the economic sustainability of the entire process. There is a lot of studies about the application of microalgae for $\mathrm{CO}_{2}$ capture, most of them related with the production of biofuels, all of them concluding that the reliability of the process is highly dependent on the strains tested, production scale/technology and final application of the biomass. Moreover, the large surface and the overall cost of the technology are actually bottlenecks for the commercial development of microalgae-based $\mathrm{CO}_{2}$ capture processes. ${ }^{16-19}$

In the last years, the large scale production of microalgae is fast increasing mainly by two reasons: (i) the enlargement of the market as microalgae biomass is now included in more food/feed products, and (ii) the improvement of the technology allowing to increase the biomass productivity, thus reducing the biomass production costs. Some important advances includes the development of more robust strains (improved strains non genetically modified), improvement of energy utilization efficiency and mass transfer capacity on the reactors, and development of new downstream strategies and products. ${ }^{20-24}$ These advances make the possibility of using microalgae for $\mathrm{CO}_{2}$ capture process much more realistic today than twenty years ago, especially if combined with the treatment of other wastes as wastewater or manure. ${ }^{19,25}$ Thus, the growth potential of microalgae-based methods can be up to 100 times faster than terrestrial plants, thus achieving productivities of $100 \mathrm{tn} / \mathrm{ha} \cdot$ year. To achieve these figures, large amounts of nutrients are required: for each tonne of biomass produced, it takes up to $2 \mathrm{tnCO}_{2}, 100 \mathrm{kgN}$ and $10 \mathrm{kgP}$. This can actually be provided by flue gases and wastewater. ${ }^{20}$ Additionally, large surfaces and adequate environmental conditions (light, temperature, etc..) are required, factors such as $\mathrm{pH}$, temperature and light intensity have a great influence on the growth dynamics of microalgae as do the nutrients 26. 
The aim of this work is to re-think the $\mathrm{CO}_{2}$ capture process taking into account the actual technology available in order to determine the real suitability of novel processes at different scales. We will focus our study on zeolite-based $\mathrm{CO}_{2}$ adsorption (physicochemical process) and microalgae-based $\mathrm{CO}_{2}$ capture (biological process). In both cases, a common composition of flue gas, with varying $\mathrm{CO}_{2}$ concentrations, typical of industrial combustion activities, have been considered. On the one hand, a combination of molecular simulation, numerical modelling of the continuous PSA process and equilibrium adsorption experiments has been used to assess the potentiality of $\mathrm{CO}_{2}$ capture of the physicochemical method. On the other hand, a $100 \mathrm{~m}^{2}$ pilot scale raceway reactor has been used to evaluate the capability of the biological process under real outdoor conditions in terms of biomass production and $\mathrm{CO}_{2}$ capture efficiency. In both cases a previous screening has been done to select the optimum zeolite (physicochemical process) and the optimum microalgae strain (biological process). Figures from the reactor experiment allows to evaluate the energy consumption and cost of the biological process, and to compare it with their physicochemical counterpart. Considering final applications of the biomass the suitability of both processes at commercial scale is finally discussed.

\section{MATERIALS AND METHODS}

\subsection{Theoretical determination of adsorption isotherms in zeolites}

Adsorption isotherms were computed using Monte Carlo simulations in the Grand Canonical ensemble (GCMC). In this ensemble, the average value of the temperature, the volume, and the chemical potential remain fixed. The chemical potential directly relates to fugacity, and then fugacity to pressure by the fugacity coefficient through the PengRobinson equation of state. ${ }^{27}$ The MC trial moves employed were translation, rotation, and reinsertion of gas molecules, swap from the reservoir, and identity change for mixtures. ${ }^{27}$ Results were obtained after running $10^{3}$ equilibration and $5 \cdot 10^{3}$ production cycles, respectively. In the case of water, up to $2 \cdot 10^{6}$ production cycles were used in order to equilibrate some particular pressure points. The number of Monte Carlo steps per cycle equals the total number of molecules in the system with a minimum of 20. Described simulations are performed using the simulation code RASPA. ${ }^{28,29}$ 
Atomic interactions were taken into account by electrostatic interactions, considered by using Coulombic potential and Ewald summations; and van der Waals interactions, described by 12-6 Lennard-Jones potential. ${ }^{27}$ In both cases, the cutoff distance is set to 12 $\AA$, where the interactions are truncated and shifted with no tail corrections applied. These simulation conditions are commonly used to study adsorption in confined systems. ${ }^{30,31}$ Adsorbate molecules were all considered rigid, as they are already reported for $\mathrm{CO}_{2},{ }^{32} \mathrm{~N}_{2},{ }^{33}$ $\mathrm{O}_{2},{ }^{33}$ and $\mathrm{H}_{2} \mathrm{O} .^{34}$ Details and parameters of the interaction model used for these molecules can be found in the Supporting Information (Section A, Table S1)

Six widely employed zeolites with different geometry and topology were selected for this work (i.e. BEA, FAU, FER, ITQ-29, MFI, and MOR). Most of them are commercially available and used for different gas separations. We use a pure-silica version of these zeolites, considering them as rigid frameworks as it is well-known that the effect of zeolite flexibility is usually small in adsorption studies. ${ }^{35} \mathrm{~A}$ representation of the grid surface energy of the selected materials is presented in Fig. S1. A description of the morphology and crystalline structure of these zeolites as considered in the modeling is also included in the Supporting Information (Section B, Figure S2, Table S2).

The insertion of molecules using Monte Carlo can take place in cavities or channels experimentally accessible only for some small adsorbates, such as $\mathrm{H}_{2} \mathrm{Or}_{2} \mathrm{O}$. To avoid this artificial insertion of molecules and reproduce experimental behavior, these cavities need to be carefully blocked. ${ }^{36,37}$ As in previous works, we use Monte Carlo and Molecular Dynamics (MD) simulations to identify these inaccessible cavities. ${ }^{38,39}$ First we identify energetic preferential adsorption sites for the molecules using MC, and then MD informs about the diffusion of the molecules. These sites from which molecules are unable to escape after $0.15 \mathrm{~ns}$ were properly blocked. In RASPA, the blockage is implemented using a list of geometric descriptions of the inaccessible volumes that are automatically considered as an overlap in MC simulations. Using this methodology, sodalites in FAU and ITQ-29 and $y$-axis channels in FER were blocked for all the molecules under study (except for $\mathrm{H}_{2} \mathrm{O}$ ) due to narrow access windows do not allow diffusion of these molecules. 


\subsection{Experimental determination of adsorption isotherms in MFI zeolite}

Experimental equilibrium gas adsorption isotherms for pure gases $\left(\mathrm{CO}_{2}\right.$ and air) and for a mixture of $10 \% \mathrm{CO}_{2}$ in air were recorded on pure silica MFI zeolite at room temperature using a volumetric analyser (Micromeritics) in the pressure range between $10^{-2}$ and 120 $\mathrm{kPa}$. The zeolite was outgassed under dynamic vacuum at $623 \mathrm{~K}(1 \mathrm{~K} / \mathrm{min})$ overnight before the gas adsorption measurements. All the gases were supplied by by Air Liquide with an ultra high purity (i.e., 99.995\%). Pure silica MFI zeolite was supplied by Institute of Chemical Technology, CSIC, Spain.

\subsection{Pressure Swing Adsorption (PSA) simulations}

Typical flue gas at ambient conditions mixture $\left(0.75 \mathrm{~N}_{2}, 0.10 \mathrm{CO}_{2}, 0.11 \mathrm{O}_{2}\right.$, and 0.032 $\mathrm{H}_{2} \mathrm{O}$ at $298 \mathrm{~K}$ and 1 bar) was considered in the PSA simulations. A simple Skartrom PSA cycle in isothermal conditions was first considered to compare the separation performance of the different 6 zeolites simulated in Section 2.1, because the model resolution is quite faster than with more complex cycles. Although industrial PSA processes usually operate adiabatically, the isothermal conditions can be achieved if the bed diameter is reduced and heat exchange rate between the bed and the surroundings is increased. A detailed cycle description is presented in Fig. S3 in the Supporting Information. Operating conditions and model parameters are given in Table S3. The high pressure $\left(P_{H}\right)$ of the cycle is defined to 1 bar to avoid the energy consumption on compressing the feed gas. A low pressure $\left(\mathrm{P}_{\mathrm{L}}\right)$ of 0.1 bar is used as it is a typical limit considered for practical application of PSA technology. ${ }^{40,41}$ It is also assumed that the adsorbent crystals are agglomerated in pellets, and that mass transfer between gas and adsorbent is controlled by macropore diffusion, neglecting intracrystalline resistance. ${ }^{42}$

The multicomponent adsorption isotherms for the PSA simulations were obtained by applying the Ideal Adsorption Solution Theory (IAST) ${ }^{43}$, previously obtained by GCMC simulations. Isotherms were fitted with the Langmuir equation. ${ }^{44}$ Details of the simulations and the fit are summarized in the Supporting Information (Section C)

In order to improve the yield of the $\mathrm{CO}_{2}$ separation predicted in the previous PSA Skarstrom cycle, a dual-PSA cyle with three equalization steps in adiabatic conditions,

with MFI zeolite as adsorbent in the bed was also implemented. ${ }^{45}$ The dual-PSA cycle 
includes two coupled PSA cycles where one cycle increases the $\mathrm{CO}_{2}$ concentration to an intermediate value (rectifying PSA) and the other increases further the $\mathrm{CO}_{2}$ concentration up to the desired specification (stripping PSA). The same PSA cycle has been used for each one of the coupled cycles. The individual PSA cycle is presented in Fig. S4a in the Supporting information. Light product and tail gas are obtained at 1 bar. The way of coupling the individual PSA cycles for the dual configuration is presented in Fig. S4b. Other parameters used in the simulations (except gas velocities) are given in Table S3. To model the effect of temperature on the adsorption isotherms, the pure adsorption isotherms of all the components in MFI have been obtained by GCMC simulation, and they have been fitted with the temperature dependent Langmuir model $\left(\mathrm{q}=K_{H 0} \exp (-\Delta H / R T) p /\left(1+b_{0} \exp \right.\right.$ $(-\Delta H / R T) p)$. A comparison between the fitted isotherms and the molecular simulation data is presented in Fig. S6, and the obtained Langmuir parameters are presented in Table S6.

\subsection{Microorganisms and culture media}

Different microorganisms, microalgae and cyanobacteria, were preselected according to previous experience and the literature; more than 40 reference works being reviewed in depth for that. Only robust strains suitable for large-scale production under non-optimally controlled conditions were selected (Table S7 in the Supporting Information). Some of the microorganisms were already available at the University of Almeria whilst others were obtained from official culture collections, mainly from the Culture Collection of Algae and Protozoa (Oban, Scotland). Inoculum from all the strains were kept under controlled conditions in $1 \mathrm{~L}$ flasks, at $20{ }^{\circ} \mathrm{C}$, under constant illumination at $200 \mu \mathrm{E} \cdot \mathrm{m}^{-2} \cdot \mathrm{s}^{-1}$ provided by fluorescent lamps, with constant aeration at $0.1 \mathrm{v} / \mathrm{v} / \mathrm{min}$ with no $\mathrm{CO}_{2}$ supply in a standard Arnon culture medium. The standard culture medium was prepared using freshwater and Mann \& Myers medium prepared using fertilizers $\left(0.14 \mathrm{~g} \cdot \mathrm{L}^{-1} \mathrm{~K}\left(\mathrm{PO}_{4}\right)_{2}, 0.18 \mathrm{~g} \cdot \mathrm{L}^{-1}\right.$ $\mathrm{Mg}\left(\mathrm{SO}_{4}\right)_{2}, 0.9 \mathrm{~g} \cdot \mathrm{L}^{-1} \mathrm{NaNO}_{3}, 0.02 \mathrm{~mL} \cdot \mathrm{L}^{-1}$ Welgro, and $0.02 \mathrm{~g} \cdot \mathrm{L}^{-1}$ Kalentol), it being autoclaved at $121{ }^{\circ} \mathrm{C}$ for 15 minutes only for laboratory trials. The inoculum cultures were monitored by microscopic observation using a Leica CME microscope 40X/0.65 to verify non-contamination. 


\subsection{Laboratory photobioreactors}

Experiments were performed in bubble-column photobioreactors $(\sim 300 \mathrm{~mL})$ aerated at $0.2 \mathrm{v} / \mathrm{v} / \mathrm{min}$ with $\mathrm{pH}$ controlled at 8.0 by on-demand injection of real flue gas (from a diesel boiler). The temperature inside the reactors was kept at $25^{\circ} \mathrm{C}$ by controlling the temperature of the chamber in which the reactors are located. A total of 15 bubble-column reactors were used and each experiment was tested in triplicate. The reactors are illuminated artificially using fluorescent lamps that are automatically turned on or off to simulate the circadian solar cycle. Irradiance on the reactors surface $\left(I_{o}\right)$ varied throughout the day from zero to $1200 \mu \mathrm{E} \cdot \mathrm{m}^{-2} \cdot \mathrm{s}^{-1}$ at noon - using these values, a mean irradiance for the light period $\left(I_{\text {light }}\right)$ of $780 \mu \mathrm{E} \cdot \mathrm{m}^{-2} \cdot \mathrm{s}^{-1}$ was obtained. On a $24 \mathrm{~h}$ basis, the mean irradiance on the reactor surface $\left(\mathrm{I}_{\text {day }}\right)$ was $390 \mu \mathrm{E} \cdot \mathrm{m}^{-2} \cdot \mathrm{s}^{-1}$.

Experiments were performed in continuous mode. For this, we used inoculum from previous cultures developed in flasks but without $\mathrm{pH}$ control and under continuous illumination at $200 \mu \mathrm{E} \cdot \mathrm{m}^{-2} \cdot \mathrm{s}^{-1}$. The volume of inoculum supplied to the reactors at the beginning of the experiment was $10 \%$ of the total culture volume in the bubble column. Once the reactor was inoculated, it was operated in batch mode for 5 days, after that it was operated in semicontinuous mode at 0.3 day $^{-1}$ dilution rate (medium inlet and harvesting are performed during illuminated period), till steady state was achieved (at least two times the hydraulic retention time). During the experiments the cultures were daily monitored measuring the biomass concentration and the fluorescence of chlorophylls. Water evaporation was compensated for each day with distilled water to avoid changes in conductivity or of any nutrient in the culture broth. At the end of the experiment, when a steady state was achieved, the entire culture was harvested and the biomass was stored for biochemical composition analysis.

\subsection{Outdoor raceway}

The raceway reactor is located at the "Las Palmerillas" Research Centre, $36^{\circ} 48^{\prime} \mathrm{N}-2^{\circ}$ $43^{\prime} \mathrm{W}$, part of the Cajamar Foundation (Almería, Spain). The reactor consists of two $50 \mathrm{~m}$ long channels $(0.46 \mathrm{~m}$ high $\times 1 \mathrm{~m}$ wide $)$, both connected by $180^{\circ}$ bends at each end, with a $0.59 \mathrm{~m}^{3}$ sump $(0.65 \mathrm{~m}$ long $\times 0.90 \mathrm{~m}$ wide $\times 1 \mathrm{~m}$ deep) located $1 \mathrm{~m}$ along one of the 
channels. ${ }^{46}$ A paddlewheel system was used to recirculate the culture through the reactor at a regular velocity of $0.2 \mathrm{~m} \cdot \mathrm{s}^{-1}$, although it can be increased up to $0.8 \mathrm{~m} \cdot \mathrm{s}^{-1}$ by manipulating the frequency inverter of the engine. The $\mathrm{pH}$, temperature and dissolved oxygen in the culture were measured using appropriate probes (5083 T and 5120, Crison, Barcelona, Spain), connected to an MM44 control-transmitter unit (Crison Instruments, Spain), and data acquisition software (Labview, National Instruments) providing complete monitoring and control of the installation. The $\mathrm{pH}$ of the culture was controlled at 8.0 by on-demand injection of flue gas (from a diesel boiler), whereas temperature was not controlled; it ranged $\pm 5^{\circ} \mathrm{C}$ with respect to the daily mean air temperature, which varied from $12^{\circ} \mathrm{C}$ in winter to $28^{\circ} \mathrm{C}$ in summer. The raceway reactor was inoculated and operated in batch mode for one week, after which it was operated in semi-continuous mode at 0.2 day $^{-1}$ at a culture depth of $0.15 \mathrm{~m}$. Only samples from steady-state conditions were used. Evaporation inside the reactor was compensated by the daily addition of fresh water.

\subsection{Analytical methods}

The cultures were examined daily under a microscope, an Olympus CH20 (Olympus Corp., USA), to evaluate the cell status and to detect possible contamination. Images of the cultures were photographed for further use. Absorbance and turbidity were measured daily to monitor the evolution of the cultures. The dry weight biomass concentration $\left(C_{b}\right)$ was measured by filtering $100 \mathrm{ml}$ of culture through $1 \mu \mathrm{m}$ filters and drying it at $80^{\circ} \mathrm{C}$ in an oven over a $24 \mathrm{~h}$ period; this measurement was performed at the end of the culture. The dry weight biomass concentration values during the batch experiments were calculated from absorbance/turbidity measurements using the correlation obtained at the end of the batch culture. Biomass productivity was calculated as the product of the biomass concentration by the imposed dilution rate. The cell status was checked daily by measuring the chlorophyll fluorescence $\left(F_{v} / F_{m}\right)$ ratio with a fluorometer (AquaPen AP 100, Photon System Instruments, The Czech Republic). For this, the cells were adapted to the dark for 15 minutes prior to measurement. Absorbance in the visible range $(400-700 \mathrm{~nm})$ was measured daily using a double-beam Helios Alpha spectrophotometer and the extinction coefficient $(K a)$ was calculated by dividing the average absorbance value by the biomass concentration $(\mathrm{Cb})$ and the cuvette's light path $(d)): K_{a}=\mathrm{Abs} /\left(C_{b} d\right)$. The average 
irradiance inside the culture $\left(I_{a v}\right)$ was calculated as a function of the irradiance at the surface $\left(I_{o}\right)$, the biomass extinction coefficient $\left(K_{a}\right)$, the biomass concentration $\left(C_{b}\right)$ and the light path inside the reactor $(d):^{47}$

$$
\mathrm{I}_{\mathrm{av}}=\frac{\mathrm{I}_{\text {light }}}{\mathrm{K}_{\mathrm{a}} \cdot \mathrm{C}_{\mathrm{b}} \cdot \mathrm{p}} \cdot\left(1-\exp \left(-\mathrm{K}_{\mathrm{a}} \cdot \mathrm{C}_{\mathrm{b}} \cdot \mathrm{p}\right)\right)
$$

Because mean daily values were considered, irradiance during the light period $\left(\mathrm{I}_{\text {light }}\right)$ was used as the irradiance on the reactor surface to calculate the mean daily irradiance. The Quantum yield $\left(\Psi_{E}\right)$ is defined as the amount of biomass generated by a unit of radiation (usually a mole of photons) absorbed by the culture. Since this represents the ratio of biomass generation to absorbed photon flux, it can be calculated using ${ }^{48}$

$$
\Psi_{\mathrm{E}}=\frac{\mathrm{P}_{\mathrm{b}}}{\mathrm{F}_{\mathrm{vol}}}
$$

The photon flux absorbed through the reactor volume $\left(F_{v o l}\right)$ is calculated from the average irradiance on a culture volume basis using ${ }^{48}$

$$
\mathrm{F}_{\mathrm{vol}}=\mathrm{I}_{\mathrm{av}} \cdot \mathrm{K}_{\mathrm{a}} \cdot \mathrm{C}_{\mathrm{b}}
$$

The photosynthetic efficiency (PE) is the fraction of energy fixed into biomass as a function of the combustion heat of the biomass that was considered constant $\left(Q_{b}=20 \mathrm{MJ} / \mathrm{kg}\right)^{48}$

$$
\mathrm{PE}=\frac{\mathrm{P}_{\mathrm{b}} \cdot \mathrm{Q}_{\mathrm{b}}}{\mathrm{F}_{\mathrm{vol}}}
$$

Freeze-dried biomass taken at the end of the batch culture was analysed. Lipids were determined gravimetrically from an extract obtained with chloroform:methanol (2:1) $(\mathrm{v} / \mathrm{v}){ }^{49}$ The protein content was determined using the modified Lowry method. ${ }^{50}$ The moisture content was determined by weight losses after $24 \mathrm{~h}$ at $80^{\circ} \mathrm{C}$, whereas the ash content was determined by calcination at $550^{\circ} \mathrm{C}$ for $6 \mathrm{~h}$. The carbohydrate content of the biomass was determined as the difference remaining from $100 \%$ after taking away the protein, lipid and ash content. 


\section{RESULTS}

\section{1 $\mathrm{CO}_{2}$ adsorption capacity of commercial zeolites: equilibrium properties and materials screening}

The adsorption loadings in BEA, FAU, FER, ITQ-29, MFI, and MOR zeolites at near ambient conditions (298 K; and 1, 2 and, 10 bar) was obtained by GCMC simulation for three different typical flue gas mixtures $\left(\mathrm{N}_{2} 75 \% ; \mathrm{CO}_{2} 5 \%, 10 \%\right.$, and $15 \% ; \mathrm{H}_{2} \mathrm{O}$ at saturation conditions; and $\mathrm{O}_{2}$ up to complete the mixture). Fig. 1 shows the gas uptakes as a function of the total pressure of the system. We can observe that the inclusion of water is almost negligible in all structures, as could be expected due to the pure-silica nature of the used materials. Competition of water with the rest of adsorbates is unfavored by the hydrophobic character of material and also due the fact that is the smallest molecule under study (kinetic diameter of around $2.6 \AA$ ). ${ }^{51,52}$ Oxygen, is also almost displaced from adsorption by the other molecules, whatever is the concentration of $\mathrm{CO}_{2}$ in the mixture. Again, the size (i.e. kinetic diameter of $3.467 \AA$ ) and the low polarity of this molecule (quadrupole moment of ca. $0.39 \mathrm{D} \AA)^{51,52}$ difficult its competition with the other gases. The overall performance strongly depends on the $\mathrm{CO}_{2}$ fraction in the mixture, that is increased from 0.05 to 0.15 while the fraction of $\mathrm{N}_{2}$ is fixed at 0.75 . In the case of the lower concentration of $\mathrm{CO}_{2}, \mathrm{~N}_{2}$ prevails over $\mathrm{CO}_{2}$ in almost all the zeolites. However, as soon as the $\mathrm{CO}_{2}$ fraction is increased to 0.10 , this molecule is able to displace $\mathrm{N}_{2}$ from the main adsorption sites of the frameworks. Both molecules have similar kinetic diameters and the higher quadrupole moment of $\mathrm{CO}_{2}$ probably makes the difference between them $(4.30 \mathrm{D} \AA$ and 1.52 D $\AA$, for $\mathrm{CO}_{2}$ and $\mathrm{N}_{2}$ respectively). This effect is less visible in FAU, the structure with the highest pore volume, because there is almost no competition for the available space at our pressure conditions. This is supported by the low total loading in this structure, being in the range of the other two structures with the lowest pore volume and surface area (i.e. MOR and FER). Another interesting exception is the low reduction in $\mathrm{N}_{2}$ uptake in MOR while increasing $\mathrm{CO}_{2}$ mixture fraction. As we say, $\mathrm{CO}_{2}$ displaces $\mathrm{N}_{2}$ from the main adsorption sites, but this is not the case of the additional adsorption sites in MOR, where $\mathrm{CO}_{2}$ is rove? to not commensurate well. ${ }^{30} \mathrm{CO}_{2}$ and $\mathrm{N}_{2}$ Average Occupation Profiles (AOPs) for the three different gas mixture compositions at the highest pressure in MOR zeolite 
(Fig. S7) reveals that while $\mathrm{CO}_{2}$ is always adsorbed in the main channels, $\mathrm{N}_{2}$ migrates from the main channels to the side pockets in which it almost does not compete with $\mathrm{CO}_{2}$.
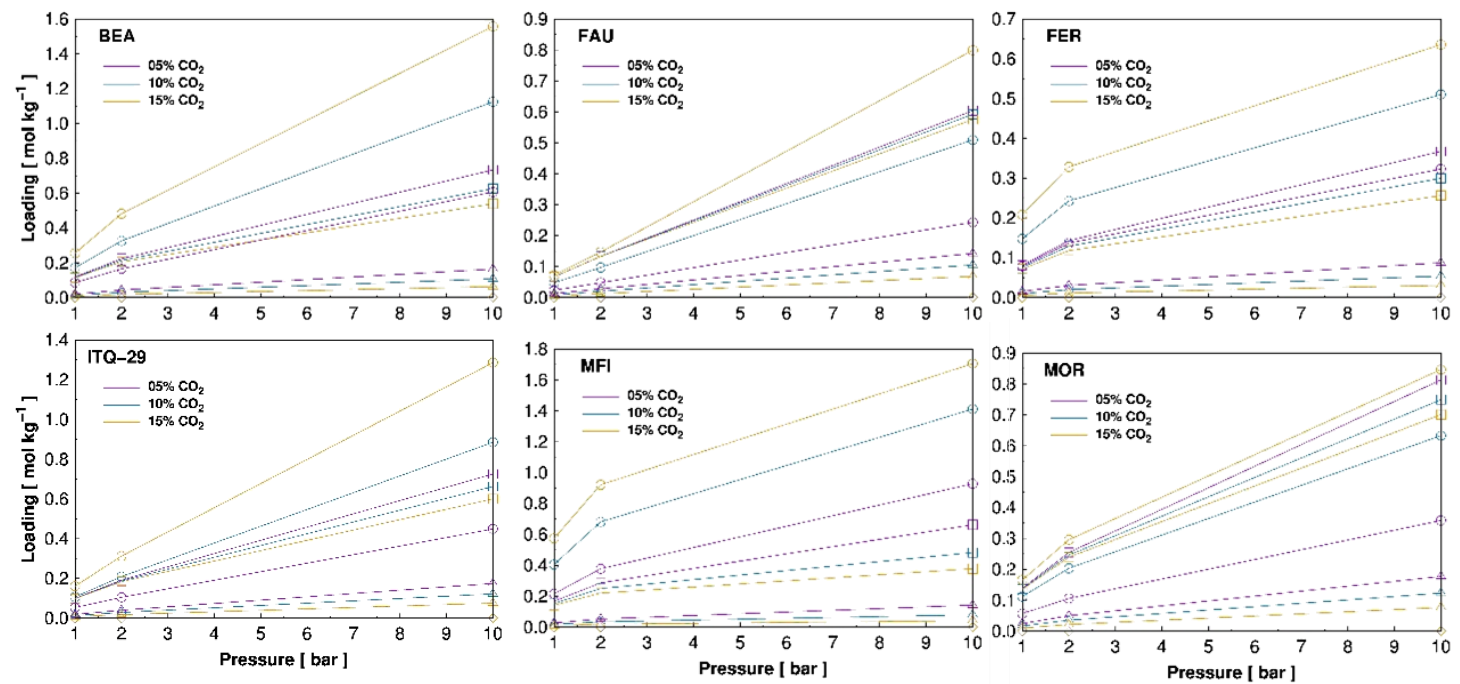

Figure 1. Adsorption loading of $\mathrm{N}_{2}$ (squares), $\mathrm{CO}_{2}$ (circles), $\mathrm{O}_{2}$ (triangles), and $\mathrm{H}_{2} \mathrm{O}$ (diamonds) in $\mathrm{BEA}$, FAU, FER, ITQ-29, MFI, and MOR zeolites at room temperature and 1,2, and 10 bar of pressure. The color line indicates the fraction of $\mathrm{CO}_{2}$ in the gas mixture.

To make a deep insight in the performance in the different zeolites, Fig. 2a collects the $\mathrm{CO}_{2}$ loadings from the computed adsorption isotherms for the mixture containing $10 \% \mathrm{CO}_{2}$ in dry air. Among all the zeolites, MFI exhibits the highest uptake for all the pressure range. Loadings of $0.4,0.7$, and $1.2 \mathrm{~mol} \mathrm{~kg}^{-1}$ are obtained at 1,2 , and 10 bar of pressure, respectively. Adsorption values are not very high due the relatively low working pressures, but the adsorbed fraction of $\mathrm{CO}_{2}$ (color graduation) is increased from 0.10 in the bulk mixture to more than 0.7 , indicating a very high selective capture towards $\mathrm{CO}_{2}$. The AOPs of $\mathrm{CO}_{2}$ in this structure (Fig. S8) show a strong adsorption of $\mathrm{CO}_{2}$ in the intersections of the straight channels parallels to the y-axis and the zig-zag channels on the xz-plane. Molecules seem to commensurate well in these adsorption sites, allowing this structure to show the best performance among the studied zeolites, both in terms of uptake and preferential adsorption. From Fig. S8 it can be also observed how zig-zag and parallel channels are progressively filled from the lowest to the highest pressure. 

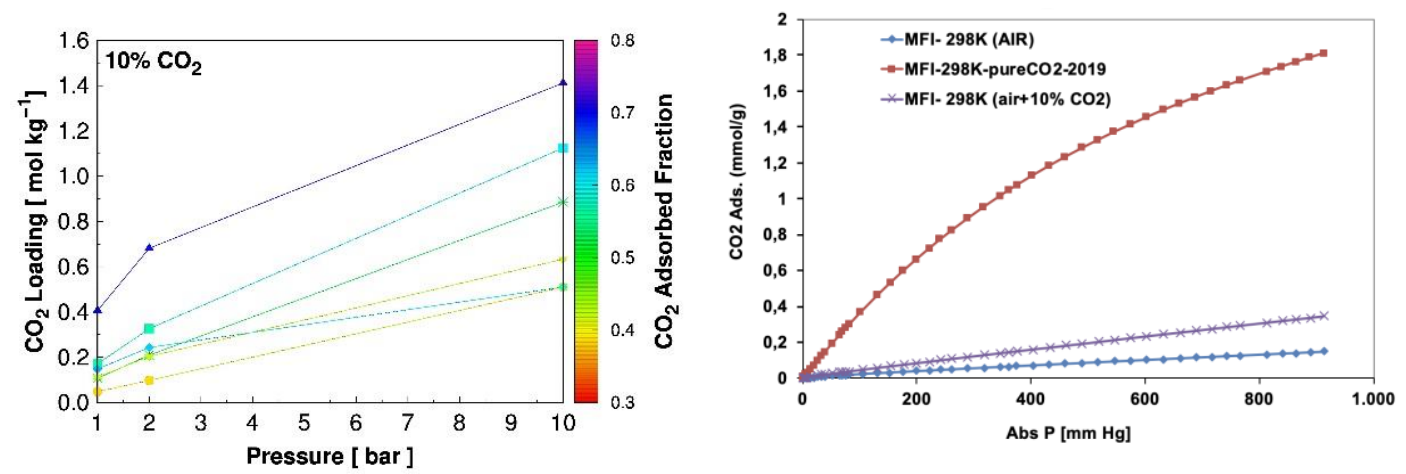

Figure 2. (A) Computed $\mathrm{CO}_{2}$ adsorption loadings in BEA (squares), FAU (circles), FER (circles), ITQ-29 (asterisks), MFI(triangles), and MOR(diamonds) zeolites at room temperature and 1, 2, and 10 bar of pressure loadings for a mixture containing $10 \% \mathrm{CO} 2$ in dry air. The color code shows the $\mathrm{CO}_{2}$ adsorbed fraction. (B) Experimental adsorption isotherms for MFI zeolite at room temperature for pure $\mathrm{CO}_{2}$, synthetic air and a mixture containing $10 \% \mathrm{CO}_{2}$ in dry synthetic air. []

BEA zeolite shows noticeably reduced $\mathrm{CO}_{2}$ loadings compared to MFI, except at 10 bar in which pressure it reached ca. $1 \mathrm{~mol} \mathrm{~kg}^{-1}$. The slightly widest system of channels explains the lower adsorption. Adsorbed molar fractions of $\mathrm{CO}_{2}$ are also quite lower, with values between 0.6 and 0.7 . The ability of the rest of zeolites to selectively capture $\mathrm{CO}_{2}$ is even worse o more limited o more restricted, barely increasing adsorbed fractions above 0.5 and showing uptakes of less than $0.3 \mathrm{~mol} \mathrm{~kg}^{-1}$ at intermediate pressure. In some structures (i.e. FAU and ITQ-29), high available pore volume and cage-type topology hinder the fitting of the molecules inside them. On the other hand, the existing preferential adsorption sites in MOR for $\mathrm{N}_{2}$, previously described, reduce the $\mathrm{CO}_{2}$ selective capture, despite having similar pore volume, surface area and channels diameters than BEA.

In order to validate the GCMC predictions, adsorption experiments for the best performing MFI zeolite were carried out. Equilibrium adsorption isotherms for pure $\mathrm{CO}_{2}$, synthetic air and a mixture containing $10 \% \mathrm{CO}_{2}$ in dry synthetic air are shown in Fig $\mathbf{2 b}$. The volumetric equipment used does not allow to discriminate the uptake corresponding to carbon dioxide in the mixture, for which the adsorption isotherm of synthetic air was also measured to estimate the contribution of nitrogen and oxygen to the adsorption of the mixture. As seen, the total amount of gas adsorbed for the mixture of $10 \% \mathrm{CO}_{2}$ in air at 
atmospheric pressure is about $15.3 \mathrm{~g} / \mathrm{Kg}$ zeolite $(0.35 \mathrm{~mol} / \mathrm{Kg})$, which is in good agreement with the amount computed for this zeolite at 1 bar. This experimental estimation is also in line with the IAST prediction for a mixture of $10 \% \mathrm{CO}_{2}$ in air evaluated from the experimental adsortpion isotherms of air and pure $\mathrm{CO}_{2}(11.4-17.2 \mathrm{~g} / \mathrm{kg})$.

\section{2 $\mathrm{CO}_{2}$ adsorption capacity of best performing zeolite: PSA estimations}

To compare the performance of each of the studied zeolites in a PSA industrial cycle, we have employed the so-called "Bed Capacity Factor" (BCF) to compare the PSA performance of each structure when using the Skarstrom cycle. ${ }^{42}$ This parameter is defined as the adsorption capacity of the column utilized at the end of adsorption step (ADS in Fig. S3, incipient breakthrough of the adsorbate) under cyclic steady state operation relative to the maximum capacity of the column under feed gas conditions. For the same operating conditions, the lower this parameter is the better is the PSA performance because the process is able to remove a higher amount of heavy adsorbate from the light product (rich in weak adsorptive). The advantage of $\mathrm{BCF}$ parameter compared to others is that it considers simultaneously the effect of the most important variables that determine separation (working capacity, adsorption rate and selectivity). For a single PSA cycle at isothermal conditions we obtained the following $\mathrm{BCF}$ values: $\mathrm{MFI}=0.21 ; \mathrm{BEA}=0.53$; FER $=0.56 ;$ MOR $=0.68 ;$ ITQ-29 $=0.80 ;$ FAU $=0.99$. These results are in close agreement with the previously obtained results from GCMC simulations (Section 3.1) and confirms that MFI offers quite better performance than the rest of structures for $\mathrm{CO}_{2}$ capture and separation from the flue gas.

On these grounds, the MFI zeolite is chosen to simulate the PSA dual cycle with three equalization steps at adiabatic conditions. As mentioned above, this type of arrangement improve the yield of $\mathrm{CO}_{2}$ separation in industrial processes. The design specifications of the dual-PSA cycle have been defined as a $\mathrm{CO}_{2}$ purity in the heavy product above $95 \%$ and $\mathrm{CO}_{2}$ recovery above $90 \%$ (calculated as global results for the two coupled cycles). The feed gas velocities of both cycles have been used as input variables to achieve the desired design specifications, resulting in a feed gas velocity of $0.0452 \mathrm{~m} \mathrm{~s}^{-1}$ for the rectifying cycle (PSA I) and $0.11 \mathrm{~m} \mathrm{~s}^{-1}$ for the stripping cycle (PSA II). A flowsheet with the molar flow rates and 
stream compositions of the designed dual cycle is shown in Fig. S4b. The performance parameters of each individual cycle and the global ones for the dual cycle are presented in Table 1. A $\mathrm{CO}_{2}$ productivity of $8.24 \mathrm{~kg} / \mathrm{m}^{3} / \mathbf{h}$ is estimated. The energy requirement for evacuation steps has been calculated assuming isoentropic compression with efficiency of $60 \%$. From Fig. S4b, it is observed that practically dry $\mathrm{CO}_{2}$ is obtained as final product. This is an advantage (apart from the possibility of treating a humid gas) because further drying of $\mathrm{CO}_{2}$ is not necessary for using it in other applications.

Table 1. Performance parameters of the designed dual-PSA cycle

\begin{tabular}{|l|c|c|c|}
\cline { 2 - 4 } \multicolumn{1}{c|}{} & PSA I & PSA II & DUAL PSA \\
\hline $\mathrm{CO}_{2}$ purity, $\%$ & 35.400 & 95.010 & 95.011 \\
\hline $\mathrm{CO}_{2}$ recovery, $\%$ & 91.870 & 80.070 & 90.040 \\
\hline $\mathrm{CO}_{2}$ productivity, $\mathrm{kgCO}_{2 \text { captured }} / \mathrm{m}_{\text {bed }}^{3} / \mathrm{h}$ & 1.140 & 8.550 & 8.240 \\
\hline Energy requirement, $\mathrm{MJ} / \mathrm{kgCO}_{2 \text { captured }}$ & 0.589 & 0.252 & 0.987 \\
\hline
\end{tabular}

\subsection{Biomass production and photosynthetic efficiency by microalgae and strain screening}

The first step in the use of microalgae for $\mathrm{CO}_{2}$ capture is the selection of the right strain. A lot of microalgae and cianobacteria strains has been investigated at this respect, in most of the cases performing batch cultures, others providing continuous light, and finally using non real flue gases. To obtain reliable figures for further scale-up processes the conditions at which the strains are evaluated must be as close as possible to that prevailing at outdoor. Here, the performance of ten previously reported microalgae/cyanobacteria has been evaluated. Fig. 3 shows that the different microalgae have largely different potential. Scenedesmus was the most productive, with values up to $1.6 \mathrm{~g} / \mathrm{L} \cdot$ day, whereas Nostoc and Spirulina were the less productive, with productivities below $0.5 \mathrm{~g} / \mathrm{L} \cdot$ day (Fig. 3A). Scenedesmus strain is widely reported under outdoor production conditions, including in $\mathrm{CO}_{2}$ capture processes, as it has demonstrated itself to be robust and suitable for outdoor production, even in non-optimal raceway reactors or using wastewaters as the nutrient source ${ }^{53,54}$. In general cyanobacteria shows a lower performance that microalgae. These values are the maximal ones because they were obtained, although under simulated outdoor 
conditions, in a well-controlled and favourable environment. The obtained figures compare well with other previously reported. Thus, using Anabaena up to $1.0 \mathrm{~g} / \mathrm{L} \cdot$ day of captured $\mathrm{CO}_{2}$ was obtained at laboratory scale, it being mainly accumulated at released exopolysaccharides. ${ }^{55}$ In terms of photosynthetic efficiency (PE, Eq. (5)) an analogous trend is observed because the light provided was the same for all the experiments and the light utilization is proportional to the biomass productivity (Fig. 3B). Crucial information in this figure is the final values, as under optimal laboratory conditions the PE can be so high as $3.0 \%$, much higher than that found in higher plants of $1 \%$. These figures justify the high potential of microalgae to efficiently use the sunlight to capture $\mathrm{CO}_{2}$ and to transform it into valuable biomass. In this respect, it has been reported that up to $200 \mathrm{tn} / \mathrm{ha}$.year of $\mathrm{CO}_{2}$ could be captured by microalgae. ${ }^{19}$
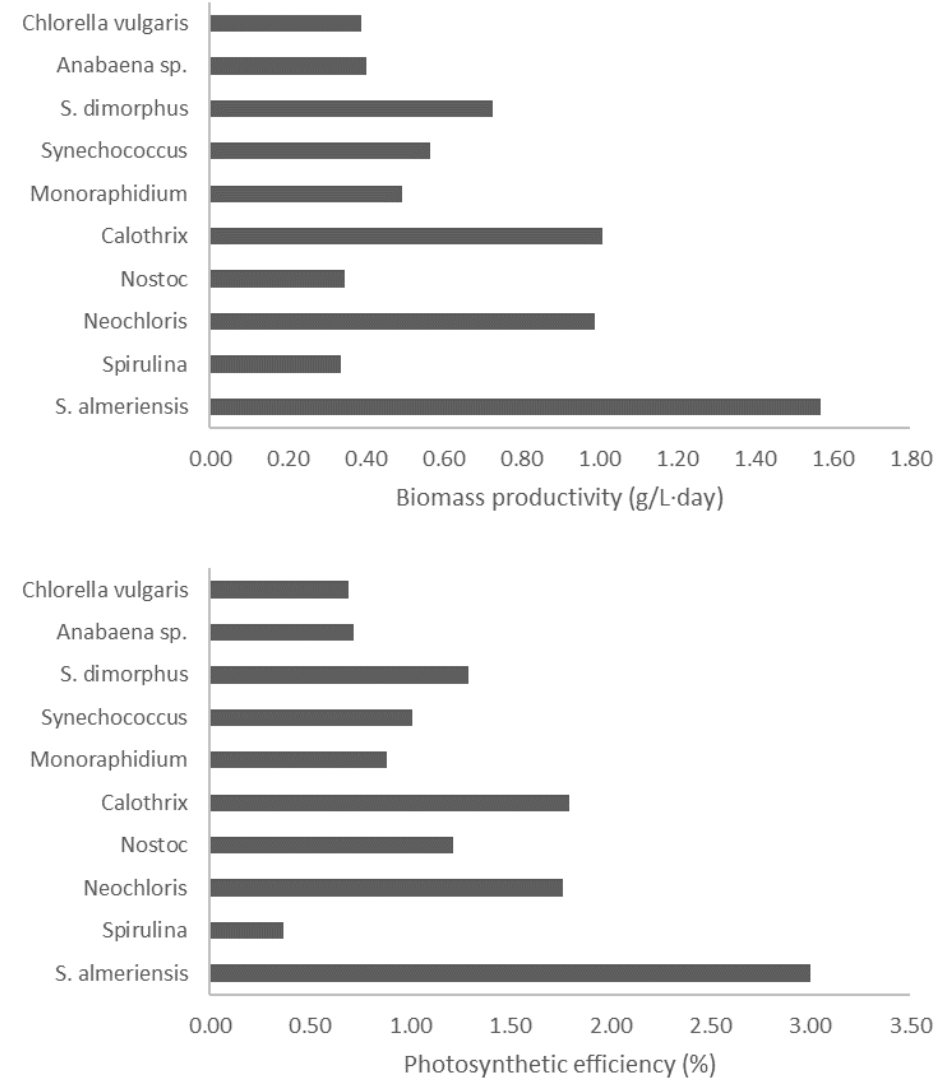

Figure 3. Biomass productivity (A) and photosynthetic efficiency (B) of microalgae strains evaluated at laboratory scale. 
To analyse the real figures about $\mathrm{CO}_{2}$ capture and how it is transformed into valuable products the theoretical $\mathrm{CO}_{2}$ fixation rate and biochemical composition of produced biomass were determined (Fig. S9 in the Supporting Information). Theoretical $\mathrm{CO}_{2}$ fixation rate correspond to the amount of $\mathrm{CO}_{2}$ fixed as biomass on the basis of biomass productivity and total carbon content of the biomass (ranging from 0.40 to $0.51 \%$ d.wt., data not shown). In addition to this value the net $\mathrm{CO}_{2}$ fixation rate can be larger if the total carbon content of the biomass increases, but it is not modified too much if the cultures are operated at continuous mode, or if the $\mathrm{CO}_{2}$ is additionally absorbed into the liquid as dissolved inorganic carbon. At laboratory scale these effects are not relevant. Hence, to consider only the net amount of $\mathrm{CO}_{2}$ fixed as biomass is a valid approximate value. Results confirm that Scenedesmus is the most promising strain, showing values up to $2.5 \mathrm{~g} / \mathrm{L} \cdot$ day, much higher than that obtained when using Nostoc or Spirulina strains (Figure S9A). In terms of biochemical composition carbohydrates and proteins were the most relevant fractions, the lipids content being always lower than $20 \%$ d.wt., except in the case of Neochloris that shows a lipids content of $26 \%$ d.wt. (Figure S9B). Neochloris is a small microalga that accumulates large amounts of lipids, up to 50\% under non-growing conditions ${ }^{56}$. This strain has been widely reported as a potential biofuel source as it is even able to grow in wastewaters ${ }^{57,58}$. In the case of Scenedesmus the percentage of carbohydrates was really high, up to $53 \%$ d.wt., but it was including higher in the case of Calothrix and Anabaena, with more than $70 \%$ d.wt. of carbohydrates. In terms of proteins, the strain showing a higher protein content was Spirulina, up to 60\%d.wt., whereas Anabaena and Calothrix shows the lowest contents, lower than $20 \%$ d.wt., in spite that all of them are cyanobacteria. Similar biochemical composition to that here showed has been previously described for Chlorella vulgaris $\left({ }^{59}\right)$, Scenedesmus $\left({ }^{60}\right)$, and Neochloris $\left({ }^{61}\right)$. The different biochemical composition of the produced biomass indicate that each one of them could be used for different purposes as biofuels, biofertilizers, animal feed, etc. ${ }^{62,63}$ However, the biomass value varies in the diverse applications so, to achieve a reliable process, it is necessary to identify a target market where the biomass value will be higher than its production cost. ${ }^{19}$

As stated in the introduction, the choosing of the final strain to be used at large scale also depends on the value of the produced biomass and the economic yield of the process 
(Fig. 4). To determine these values a standard value of proteins $(1 € / \mathrm{kg})$, lipids $(0.6 € / \mathrm{kg})$ and carbohydrates $(0.3 € / \mathrm{kg})$ has been considered, these values corresponding to the approximate price of these commodities. All the microalgae/cyanobacteria biomasses produced have an equivalent value, ranging from maximal value of $0.7 € / \mathrm{kg}$ of Spirulina, to the minimum value of $0.4 € / \mathrm{kg}$ of Anabaena (Fig. 4A). It is noticeable the high value of Neochloris because this strain have been widely reported as interesting for biodiesel production, ${ }^{56}$ in addition to Nostoc which has been reported as a robust strain suitable to be produced at large scale. ${ }^{64}$ However, Spirulina and Nostoc were some of the less productive strains. Multiplying the value of the biomass by the biomass productivity, i.e., the economic yield, is a more interesting criterion. The results that Scenedesmus is the most interesting strain in this respect, its economic yield being of $0.87 € / \mathrm{m}^{3}$. day (Fig. 4B).
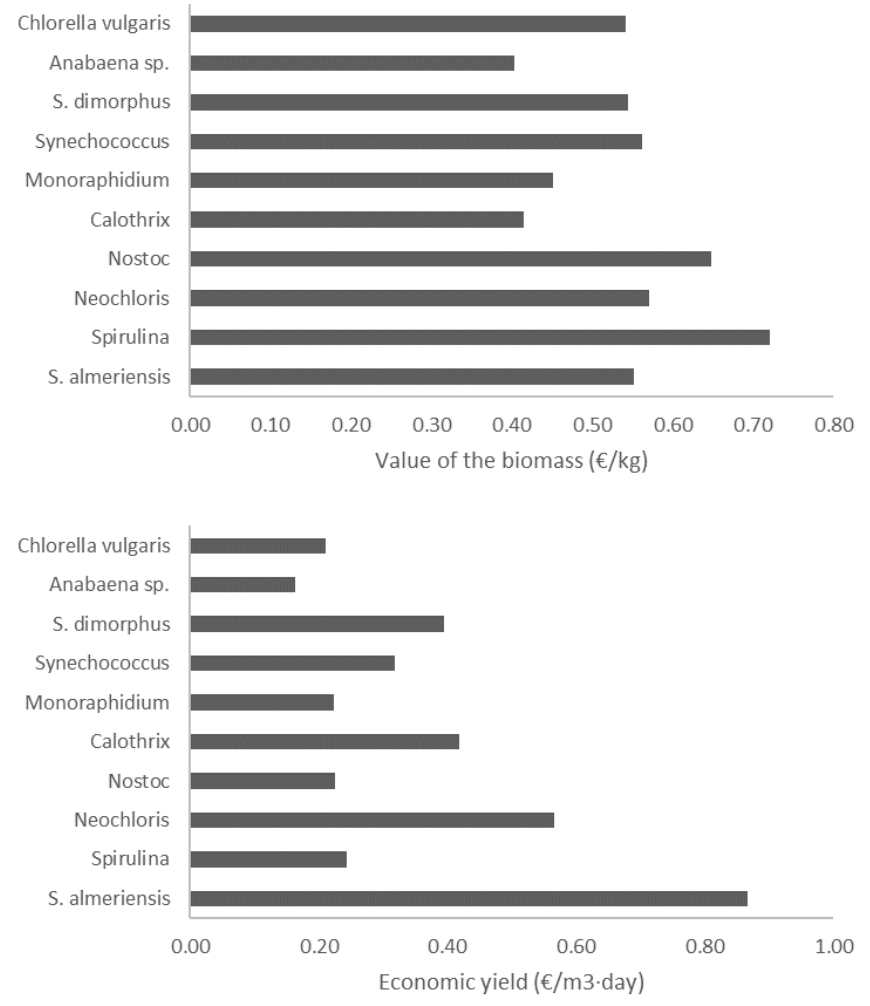

Figure 4. Value of the biomass and economic yield of the system of different strains tested at laboratory conditions.

\subsection{Biomass production and photosynthetic efficiency at outdoor conditions}


Once the optimal strain has been selected, it was tested in real outdoor conditions, using a $100 \mathrm{~m}^{2}$ pilot scale raceway reactor operated in continuous mode at 0.2 day $^{-1}$ during six months from January to June at Almeria (Spain). On this time the solar radiation changes from 11 to $30 \mathrm{MJ} / \mathrm{m}^{2}$. day whereas the mean daily temperature ranged from $12^{\circ} \mathrm{C}$ in winter time to $25^{\circ} \mathrm{C}$ in summer time. In spite of large variations of solar radiation and temperature, not only along the days but also in each solar cycle, the cultures of Scenedesmus perform adequately, no large contamination problems existing and the culture being stable for long time (Fig. 5). Data shows as the biomass productivity increases from 10 to $30 \mathrm{~g} / \mathrm{m}^{2}$.day from January to June mainly by the increase on solar radiation availability. On this time the photosynthetic efficiency did not change too much, a really high mean value of $2.0 \%$ being measured. These values confirm the adequacy of the selected strain to be used in large scale $\mathrm{CO}_{2}$ capture processes. 

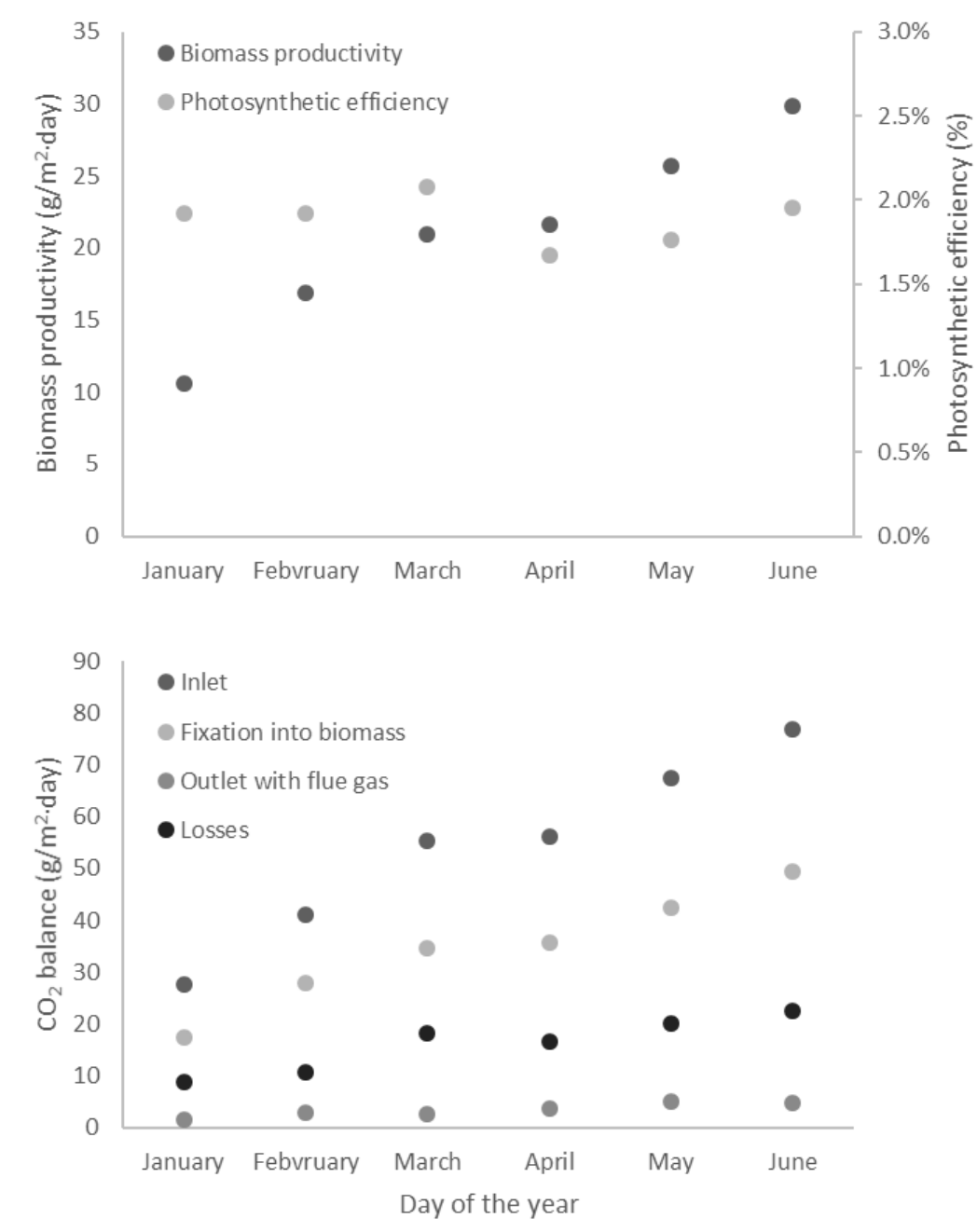

Figure 5. Variation of biomass productivity and photosynthetic efficiency (A), in addition to $\mathrm{CO}_{2}$ inlet and outlet streams, of outdoor continuous cultures of Scenedesmus almeriensis in a $100 \mathrm{~m}^{2}$ pilot scale raceway reactor located in Almeria (Spain).

To determine the real $\mathrm{CO}_{2}$ capture capacity, the mass flow of $\mathrm{CO}_{2}$ entering to the reactor was measured, in addition to the net amount of $\mathrm{CO}_{2}$ fixed into the biomass, and the $\mathrm{CO}_{2}$ losses with the flue gases exhausting the reactor. The difference between the $\mathrm{CO}_{2}$ inlet and the $\mathrm{CO}_{2}$ outlet with the biomass and the flue gases was calculated as overall $\mathrm{CO}_{2}$ losses. The results indicate that the $\mathrm{CO}_{2}$ demand of the system increases when increasing the biomass productivity, due to the control system used to maintain the $\mathrm{pH}$ at its optimal value (Fig. 5b). The total $\mathrm{CO}_{2}$ demand ranged from 27.6 to $76.7 \mathrm{~g} / \mathrm{m}^{2}$. day. This $\mathrm{CO}_{2}$ was mainly consumed by the biomass, their values ranging from 17.5 to $49.3 \mathrm{~g} / \mathrm{m}^{2} \cdot$ day. The larger amount of $\mathrm{CO}_{2}$ supplied with respect to the net amount fixed into the biomass was 
due to the efficiency of the $\mathrm{CO}_{2}$ supply system. Thus, $\mathrm{CO}_{2}$ losses by non-absorption of $\mathrm{CO}_{2}$ contained into the flue gases injected ranges from 1.4 to $4.8 \mathrm{~g} / \mathrm{m}^{2} \cdot$ day. These values are really minor when comparing with total $\mathrm{CO}_{2}$ supplied, indicating the adequate performance of the $\mathrm{CO}_{2}$ gas supply system. However, still a large fraction of $\mathrm{CO}_{2}$ was lost, ranging from 8.7 to $22.6 \mathrm{~g} / \mathrm{m}^{2}$. day. These losses can be due to decarbonisation into the entire raceway reactor or carbon outlet with the outlet culture broth when harvesting. Anyway, the total amount of $\mathrm{CO}_{2}$ demanded by the system was $\mathbf{5 4} \mathbf{g} / \mathbf{m}^{\mathbf{2}} \cdot$ day, equivalent to $197 \mathrm{t} / \mathrm{ha} \cdot$ year. This means that the $\mathrm{CO}_{2}$ demand to biomass productivity ratio is 2.58 , instead of the 1.83 value theoretically obtained if considering the basic equation of photosynthesis. This is an important fact considering $\mathrm{CO}_{2}$ emissions at ground level or the increase of inorganic carbon concentration in the exhausted water for its final disposal. On average, the $\mathrm{CO}_{2}$ fixation into the biomass represent $64.0 \%$ of the total $\mathrm{CO}_{2}$ inlet, whereas $\mathrm{CO}_{2}$ losses with the exhaust gas represent $9.6 \%$ of the total $\mathrm{CO}_{2}$ inlet, then the remaining $\mathrm{CO}_{2}$ losses representing up to $26.4 \%$ of total $\mathrm{CO}_{2}$ inlet. Although raceway reactors are the most suitable for $\mathrm{CO}_{2}$ capture-related processes other technologies has been previously studied. By comparing the performance of Anabaena cultures carried out in raceway, tubular photobioreactors and flat panels, the optimal value of $35 \mathrm{~g} / \mathrm{m}^{2}$.day was achieved in flat panels reactors. ${ }^{65}$ However, the scale-up of this technology is still a major issue in microalgae biotechnology field.

\section{DISCUSSION}

As mentioned in the introduction the purpose of this work is to analyze and compare the capability of $\mathrm{CO}_{2}$ capture by a physicochemical means (adsorption in porous media) and by biological means (biomass production by microalgae). In this respect, not only the rate of $\mathrm{CO}_{2}$ capture is of importance, but also the energy requirements of the process and the valorization of the final product.

As regards the former, the separation performance of the proposed dual-PSA process with the best performing zeolite MFI provides a figure of $8 \mathrm{~kg} \mathrm{~m}^{-3}$ bed h $\mathrm{h}^{-1}$, which is substantially higher that previously reported data by microalgae $\left(0.04-0.25 \mathrm{~kg} \mathrm{~m}^{-3}\right.$ broth h $\left.{ }^{1}\right)^{66}$ and the data presented in this work: $0.00225 \mathrm{~kg} \mathrm{~m}^{-2} \mathrm{~h}^{-1}$. On the other hand the energy requirement is lower than the one of amine scrubbing processes $\left(0.37 \mathrm{kWh} / \mathrm{kgCO}_{2 \text { captured }}=\right.$ 
$1.3 \mathrm{MJ} / \mathrm{kgCO}_{2 \text { captured }) .}{ }^{67}$ As regards the economic aspect, the obtained product (high purity $\mathrm{CO}_{2}$ ) can be used in many applications, such as the obtention of carbon monoxide, methane or methanol.

With respect to the biological alternative, it must borne in mind that the $\mathrm{CO}_{2}$ supply system must be accurately designed to avoid reemission of $\mathrm{CO}_{2}$ to the atmosphere. Carbon dioxide can be supplied to microalgae cultures by (a) continuous bubbling or (b) ondemand injection. With continuous bubbling of flue gases, the medium becomes acidic and maximum $\mathrm{CO}_{2}$ use efficiencies of only $8.1 \%{ }^{68}$ and $4.2 \%{ }^{69}$ have been reported. With ondemand injection of flue gases, a maximum $\mathrm{CO}_{2}$ use efficiency of $32.8 \%$ in open photobioreactors ${ }^{70}$ and $50 \%$ in closed photobioreactors ${ }^{71}$ have been determined. In both strategies, the consumption of $\mathrm{CO}_{2}$ is a function of the design and the operation of the carbonation unit, and finally, of the mass transfer phenomena into the culture. In a different strategy the $\mathrm{CO}_{2}$ can be provided dissolved into the culture medium by passing it by a previous carbonation unit, up to $2.0 \mathrm{~g} / \mathrm{L}$ of total inorganic carbon being dissolved into the culture medium suitable to be consumed by Anabaena ${ }^{72}$. Recently the $\mathrm{CO}_{2}$ capture efficiency in raceway reactors has been re-designed by including a sump into the reactor, and optimizing its design and gas/liquid flow rates. It was demonstrated that under optimal conditions de $\mathrm{CO}_{2}$ transfer efficiency was up to $98 \%{ }^{73}$.

On top of all these considerations, the energy consumption and cost of the biological process must also be analysed. In the case of energy, the major energy inlet on raceway reactors is the power required by the paddlewheel. To minimize the energy consumption, raceway reactors are build following some key rules, as a length to wide ratio of 10 , using softer as possible materials, reducing the liquid velocity up to $0.2 \mathrm{~m} / \mathrm{s}$, and minimizing the presence of bends and other structural parts that disturb the flow along the channels ${ }^{74}$. Recently the design of this type of reactors has been reviewed to minimize its energy consumption. In this respect a new Low Energy Algae Reactor (LEAR Patent EP2875724A1) has been patented. Thus, energy consumption in raceway reactors can be reduced from 20 to $1 \mathrm{~W} / \mathrm{m}^{3},{ }^{21}$ or including below $1 \mathrm{~W} / \mathrm{m}^{3}$ if using LEAR system. During the operation of the $100 \mathrm{~m}^{2}$ pilot scale raceway reactor the measured energy consumption was $2 \mathrm{~W} / \mathrm{m}^{3}$, thus it being equivalent to $0.48 \mathrm{MJ} / \mathrm{kg}$ of $\mathrm{CO}_{2}$ captured, which is substantially 
lower than the chemical (amines scrubbing) and physicochemical (zeolite adsorption) procedures.

In Fig. 6 the influence of biomass productivity and specific energy consumption on the raceway reactor into the specific energy consumption per $\mathrm{kg}$ of $\mathrm{CO}_{2}$ captured is analized. It is confirmed that microalgae based processes have lower energy consumption that amines-based processes only when specific energy consumption of the reactor are lower than $20 \mathrm{~W} / \mathrm{m}^{3}$ and at biomass productivities are higher than $25 \mathrm{~g} / \mathrm{m}^{2}$. day. When comparing with zeolites-based processes the microalgae have lower energy consumption only when operating at specific energy consumption in the raceway reactor lower than 2 $\mathrm{W} / \mathrm{m}^{3}$ and biomass productivities higher than $15 \mathrm{~g} / \mathrm{m}^{2}$.day. Anyway, these figures show that the microalgae-based processes for $\mathrm{CO}_{2}$ capture are in the same range of energy consumption than low energy demanding technologies as PSA with zeolites. In terms of cost, the biomass production cost in this type of raceway reactors can be reduced till 2.1 $€ / \mathrm{kg}$ when using flue gases and minimum manpower $(0.1 \mathrm{men} / \mathrm{ha})$, it being equivalent to a $\mathrm{CO}_{2}$ capture cost of $0.8 € / \mathrm{kg}^{75}$. This production cost is much higher than conventional price of industrial pure $\mathrm{CO}_{2}$, ranging from $0.1-0.2 € / \mathrm{kg}$. However, the price of microalgae biomass is much higher than of pure $\mathrm{CO}_{2}$, minimum values of $5 € / \mathrm{kg}$ being reported ${ }^{76}$. Considering this price for the biomass, the value of $\mathrm{CO}_{2}$ contained into the biomass is 1.9 $€ / \mathrm{kg}$, much higher than estimated $\mathrm{CO}_{2}$ capture cost of $0.8 € / \mathrm{kg}$. Thus, to achieve a suitable commercial process for $\mathrm{CO}_{2}$ capture, it is necessary to produce valuable biomass otherwise the production cost will be higher than the $\mathrm{CO}_{2}$ emission taxes ${ }^{19}$. 


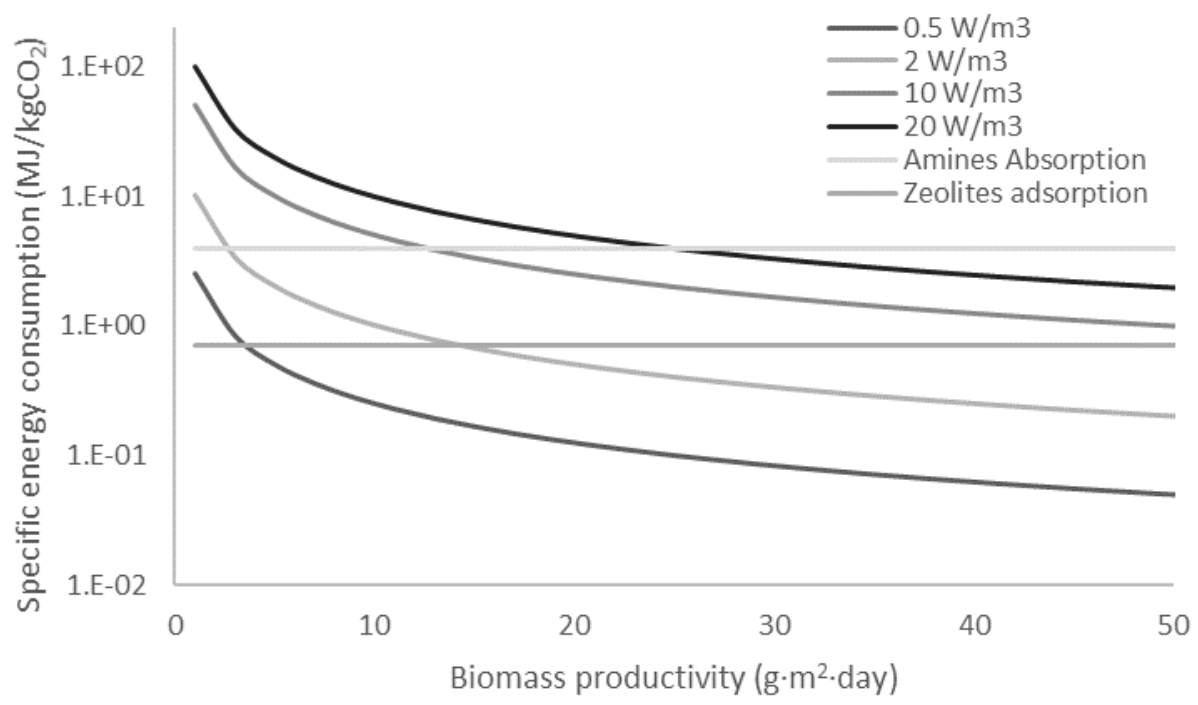

Figure 6. Variation of energy consumption of microalgae based processes as a function of biomass productivity and specific energy consumption of the reactor.

\section{CONCLUSIONS}

The alternative capabilities of a physicochemical (adsorption in porous media) and a biological process (biomass production by microalgae) to capture $\mathrm{CO}_{2}$ from flue gases has been analysed, assessed and compared.

In connection to the physicochemical alternative, GEMC simulations and adsorption experiments demonstrate that commercial zeolite MFI is the best candidate to capture this gas due to the morphology and crystalline structure of this material. Numerical simulation of a dual PSA cycle suitable for industrial implementation confirms this finding and provide an estimated value for $\mathrm{CO}_{2}$ capture of $8 \mathrm{~kg} \mathrm{~m}^{-3}$ bed $\mathrm{h}^{-1}$ and an energy compsuption of $0.987 \mathrm{MJ} / \mathrm{Kg}$ of captured $\mathrm{CO}_{2}$.

In connection to the biological alternative, it is demonstrated that microalgae-based processes for capturing $\mathrm{CO}_{2}$ from flue gases can be performed, being reliable at real outdoor operation conditions for more than six months. The key factors determining the reliability of the process are the selection of adequate strains and technologies. From the up to ten microalgae/cyanobacteria strains evaluated, the fast growing and robust Scenedesmus

almeriensis was the more productive, up to $0.06 \mathrm{~kg} \mathrm{~m}^{-3}$ broth $\mathrm{h}^{-1}$. The production of this 
strain in a $100 \mathrm{~m}^{2}$ pilot scale raceway reactor at real outdoor conditions was demonstrated, allowing to capture up to $54 \mathrm{gCO}_{2} / \mathrm{m}^{2}$. day in average from January to June. The strategy of on-demand supply of $\mathrm{CO}_{2}$ and optimal mass transfer capacity into the reactor allows to capture up to $2.58 \mathrm{kgCO}_{2}$ per $\mathrm{kg}$ of produced biomass, only $9.6 \%$ of the supplied $\mathrm{CO}_{2}$ being lost to the atmosphere. Energy consumption of the process was estimated at 0.48 $\mathrm{MJ} / \mathrm{kgCO}_{2}$, the unitary cost being $0.8 € / \mathrm{kg}$ of $\mathrm{CO}_{2}$. The energy consumption is lower than the physicochemical process, but the cost is much high than regular price of pure $\mathrm{CO}_{2}$. However, value of the microalgae biomass is much higher thus it being concluded that captured $\mathrm{CO}_{2}$ have a value equivalent to $1.9 € / \mathrm{kg}$. These figures provide a realistic scenario about the potential application of microalgae to $\mathrm{CO}_{2}$ capture related processes.

Although the major bottleneck of microalgae-based processes is the necessity of high sunlight and land availability, this technology can be an alternative for diffuse $\mathrm{CO}_{2}$ emission from small industries and farms, among others. Physicochemical processes do not depend on ambient conditions and land availability but rely on a suitable use and management of the resulting stream of pure $\mathrm{CO}_{2}$ obtained.

\section{ACKNOWLEDGEMENTS}

This study was carried out with the financial support of Junta de Andalucía, grant FQM 1851 and the company, SETEC. We are grateful for the practical assistance kindly given by the staff of the Las Palmerillas Experimental Station, part of the Cajamar Foundation.

\section{REFERENCES}

1 Anonymous, Paris Agreement, https://ec.europa.eu/clima/policies/international/negotiations/paris_en, (accessed 16 March 2019).

2 M. Collins, R. Knutti, J. Arblaster, J.-L. Dufresne, T. Fichefet, P. Friedlingstein, X. Gao, W. J. Gutowski, T. Johns, G. Krinner, M. Shongwe, C. Tebaldi, A. J. Weaver and M. Wehner, Clim. Change 2013 Phys. Sci. Basis Contrib. Work. Group Fifth Assess. Rep. Intergov. Panel Clim. Change, 2013, 1029-1136. 
3 E. Herzog, H., Drake E., Adams, EM Featrure, 1997, 22-24.

4 O. US EPA, Sources of Greenhouse Gas Emissions, https://www.epa.gov/ghgemissions/sources-greenhouse-gas-emissions, (accessed 16 March 2019).

5 C.-H. Yu, C.-H. Huang and C.-S. Tan, Aerosol Air Qual. Res., 2012, 12, 745-769.

6 G. T. Rochelle, Science, 2009, 325, 1652-1654.

7 J.-L. Li and B.-H. Chen, Sep. Purif. Technol., 2005, 41, 109-122.

8 M. J. Tuinier, H. P. Hamers and M. van Sint Annaland, Int. J. Greenh. Gas Control, $2011,5,1559-1565$.

9 Global CCS Institute, The global status of ccs: 2011, 2011.

10M. T. Ho, G. W. Allinson and D. E. Wiley, Ind. Eng. Chem. Res., 2008, 47, 4883-4890.

11Q. Wang, J. Luo, Z. Zhong and A. Borgna, Energy Environ. Sci., 2010, 4, 42-55.

12Z. Zhao, Z. Li and Y. S. Lin, Ind. Eng. Chem. Res., 2009, 48, 10015-10020.

13J. M. Vicent-Luna, J. J. Gutiérrez-Sevillano, J. A. Anta and S. Calero, J. Phys. Chem. C, 2013, 117, 20762-20768.

14E. Hughes and J. R. Benemann, Energy Convers. Manag., 1997, 38, S467-S473.

15U. B. Singh and A. S. Ahluwalia, Mitig. Adapt. Strateg. Glob. Change, 2013, 18, 73-95.

16S.-H. Ho, C.-Y. Chen, D.-J. Lee and J.-S. Chang, Biotechnol. Adv., 2011, 29, 189-198.

17J. C. M. Pires, M. C. Alvim-Ferraz, F. G. Martins and M. Simões, Renew. Sustain. Energy Rev., 2012, 16, 3043-3053.

18 W. Zhou, J. Wang, P. Chen, C. Ji, Q. Kang, B. Lu, K. Li, J. Liu and R. Ruan, Renew. Sustain. Energy Rev., 2017, 76, 1163-1175.

19F. G. Acien, C. V. González-López, J. M. Fernández-Sevilla and E. Molina-Grima, Appl. Microbiol. Biotechnol., 2012, 96, 577-586.

20M. R. Tredici, Biofuels, 2010, 1, 143-162.

21 J. L. Mendoza, M. R. Granados, I. de Godos, F. G. Acién, E. Molina, C. Banks and S. Heaven, Biomass Bioenergy, 2013, 54, 267-275.

22 J. L. Mendoza, M. R. Granados, I. de Godos, F. G. Acién, E. Molina, S. Heaven and C. J. Banks, Bioresour. Technol., 2013, 137, 188-195.

23R. K. Desai, M. Streefland, R. H. Wijffels and M. H. M. Eppink, Green Chem., , DOI:10.1039/c3gc42631a.

24S. De Caralt, M. J. Uriz and R. H. Wijffels, J. Mar. Biol. Assoc. U. K., , DOI:10.1017/S0025315407056846.

25F. G. Acién, C. Gómez-Serrano, M. M. . Morales-Amaral, J. M. Fernández-Sevilla and

E. Molina-Grima, Appl. Microbiol. Biotechnol., 2016, 100, 9013-9022.

26S. Venkata Mohan, M. V. Rohit, P. Chiranjeevi, R. Chandra and B. Navaneeth, Bioresour. Technol., , DOI:10.1016/j.biortech.2014.10.056.

27D. Frenkel and B. Smit, Understanding Molecular Simulations: From Algorithms to Applications, C. Academic Press, San Diego, CA, second edi., 2002.

28D. Dubbeldam, S. Calero, D. E. Ellis and R. Q. Snurr, Mol. Simul., 2015, 42, 81-101. 29D. Dubbeldam, A. Torres-Knoop and K. S. Walton, Mol. Simul., 2013, 39, 1253-1292.

30I. Matito-Martos, A. Martin-Calvo, J. J. Gutiérrez-Sevillano, M. Haranczyk, M. Doblare, J. B. Parra, C. O. Ania and S. Calero, Phys Chem Chem Phys, 2014, 16, 19884--19893.

31E. Garcia-Perez, J. B. Parra, C. O. Ania, A. Garcia-Sanchez, J. M. Van Baten, R. Krishna, D. Dubbeldam and S. Calero, Adsorpt.-J. Int. Adsorpt. Soc., 2007, 13, 469-476. 32 A. Garcia-Sanchez, C. O. Ania, J. B. Parra, D. Dubbeldam, T. J. H. Vlugt, R. Krishna and S. Calero, J. Phys. Chem. C, 2009, 113, 8814-8820. 
33 A. Martin-Calvo, E. Garcia-Perez, A. Garcia-Sanchez, R. Bueno-Perez, S. Hamad and S. Calero, Phys. Chem. Chem. Phys., 2011, 13, 11165-11174.

34S. W. Rick, J. Chem. Phys., 2004, 120, 6085-6093.

35T. J. H. Vlugt and M. Schenk, J. Phys. Chem. B, 2002, 106, 12757-12763.

36S. Calero, D. Dubbeldam, R. Krishna, B. Smit, T. J. H. Vlugt, J. F. M. Denayer, J. A.

Martens and T. L. M. Maesen, J. Am. Chem. Soc., 2004, 126, 11377-11386.

37R. Krishna and J. M. van Baten, Langmuir, 2010, 26, 2975-2978.

38I. Matito-Martos, J. Álvarez-Ossorio, J. J. Gutiérrez-Sevillano, M. Doblaré, a. Martin-

Calvo and S. Calero, Phys Chem Chem Phys, 2015, 17, 18121-18130.

39I. Matito-Martos, A. Rahbari, A. Martin-Calvo, D. Dubbeldam, T. J. H. Vlugt and S.

Calero, Phys. Chem. Chem. Phys., 2018, 20, 4189-4199.

40S. Effendy, C. Xu and S. Farooq, Ind. Eng. Chem. Res., 2017, 56, 5417-5431.

41 J. Park, R. P. Lively and D. S. Sholl, J Mater Chem A, 2017, 5, 12258-12265.

42R. R. Vemula and S. Sircar, AIChE J., 63, 4066-4078.

43 A. L. Myers and J. M. Prausnitz, AIChE J., 1965, 11, 121-127.

44I. Langmuir, J. Am. Chem. Soc., 1918, 40, 1361-1403.

45C. A. Grande and R. Blom, Energy Procedia, 2012, 26, 2-14.

46M. Barceló-Villalobos, J. L. Guzmán Sánchez, I. Martín Cara, J. A. Sánchez Molina and

F. G. Acién Fernández, Algal Res., 2018, 35, 91-97.

47J. M. Fernández-Sevilla, E. Molina-Grima, F. García-Camacho, F. G. Acién and J. A.

Sánchez-Pérez, Appl. Microbiol. Biotechnol., 1998, 50, 199-205.

48E. Molina Grima, F. García Camacho, J. A. Sánchez Pérez, F. G. Acién, J. M. M.

Fernández Sevilla, J. A. Sánchez Pérez, F. G. Acién Fernández and J. M. M. Fernández

Sevilla, J. Appl. Phycol., 1996, 8, 529-534.

49G. Kochert, Handb. Phycol. Methods, 1978, 2, 95-97.

50C. V. González López, M. del C. Cerón García, F. G. Acién Fernández, C. Segovia

Bustos, Y. Chisti and J. M. Fernández Sevilla, Bioresour. Technol., 2010, 101, 75877591.

51 S. Sircar, Ind. Eng. Chem. Res., 2006, 45, 5435-5448.

52J.-R. Li, R. J. Kuppler and H.-C. Zhou, Chem. Soc. Rev., 2009, 38, 1477-1504.

53 M. M. Morales-Amaral, C. Gómez-Serrano, F. G. Acién, J. M. Fernández-Sevilla and E.

Molina-Grima, Algal Res., 2015, 9, 297-305.

54T. Duarte-Santos, J. L. Mendoza-Martín, F. G. Acién Fernández, E. Molina, J. A. Vieira-

Costa and S. Heaven, Bioresour. Technol., 2016, 212, 72-81.

55J. F. S. Fernández, C. V. González-López, F. G. A. Fernández, J. M. F. Sevilla and E. M.

Grima, Appl. Microbiol. Biotechnol., , DOI:10.1007/s00253-011-3683-7.

56J. Pruvost, G. Van Vooren, G. Cogne and J. Legrand, Bioresour. Technol., 2009, 100, 5988-5995.

57L. Gouveia, A. E. Marques, T. L. Da Silva and A. Reis, J. Ind. Microbiol. Biotechnol., 2009, 36, 821-826.

58C. Gómez-Serrano, M. M. Morales-Amaral, F. G. Acién, R. Escudero, J. M. FernándezSevilla and E. Molina-Grima, Appl. Microbiol. Biotechnol., 2015, 99, 6931-6944.

59C. D. Calixto, J. K. da Silva Santana, E. B. de Lira, P. G. P. Sassi, R. Rosenhaim, C. F. da Costa Sassi, M. M. da Conceição and R. Sassi, Bioresour. Technol., 2016, 221, 438446.

60L. Yao, J. A. Gerde, S. L. Lee, T. Wang and K. A. Harrata, J. Agric. Food Chem., 2015, 63, 1773-1787. 
61C. A. Popovich, C. Damiani, D. Constenla, A. María Martínez, H. Freije, M. Giovanardi, S. Pancaldi and P. I. Leonardi, , DOI:10.1016/j.biortech.2012.02.121.

62Q. Hu, M. Sommerfeld, E. Jarvis, M. Ghirardi, M. Posewitz, M. Seibert and A. Darzins, 2008, 54, 621-639.

63 A.-M. Lakaniemi, O. H. Tuovinen and J. A. Puhakka, Bioresour. Technol., 2013, 135, 222-31.

64R. Piccardi, A. Frosini, M. R. Tredici and M. C. Margheri, J. Appl. Phycol., 2000, 12, 543-547.

65 M. E. Clares, J. Moreno, M. G. Guerrero and M. García-González, J. Biotechnol., 2014, 187, 51-55.

66A. Ghorbani, H. R. Rahimpour, Y. Ghasemi, S. Zoughi and M. R. Rahimpour, Renew. Sustain. Energy Rev., 2014, 35, 73-100.

67G. T. Rochelle, Science, 2009, 325, 1652-1654.

68Z. Cheng-wu, O. Zmora, R. Kopel and A. Richmond, Aquaculture, 2001, 195, 35-49.

69Q. Hu, N. Kurano, M. Kawachi, I. Iwasaki and S. Miyachi, Appl.Microbiol.Biotechnol., 1998, 49, 655-662.

70J. Doucha, F. Straka, K. Lívanský and K. Lívanský, J. Appl. Phycol., 2005, 17, 403-412.

71F. Camacho Rubio, F. G. Acién Fernández, J. A. Sánchez Pérez, F. García Camacho and E. Molina Grima, Biotechnol. Bioeng., 1999, 62, 71-86.

72C. V. V González-López, F. G. A. Fernández, J. M. M. Fernández-Sevilla, J. F. S. Fernández, E. M. Grima, C. V. Gonz??lez-L??pez, F. G. Aci??n Fern??ndez, J. M. Fern??ndez-Sevilla, J. F. S??nchez Fern??ndez, E. Molina Grima, C. V. V GonzálezLópez, F. G. Acién Fernández, J. M. M. Fernández-Sevilla, J. F. Sánchez Fernández, E. Molina Grima, F. G. A. Fernández, J. M. M. Fernández-Sevilla, J. F. S. Fernández and E. M. Grima, Biotechnol. Bioeng., 2012, 109, 1637-1650.

73I. de Godos, J. L. Mendoza, F. G. Acién, E. Molina, C. J. Banks, S. Heaven and F. Rogalla, Bioresour. Technol., 2014, 153, 307-314.

74J. C. Weissman and R. P. Goebel, Design and analysis of microalgal open pond systems for the purpose of producing fuels: A subcontract report, 1987.

75F. G. Acién, J. M. Fernández, J. J. Magán and E. Molina, Biotechnol. Adv., 2012, 30, 1344-1353.

76P. Spolaore, C. Joannis-Cassan, E. Duran and A. Isambert, J. Biosci. Bioeng., 2006, 101, 87-96. 


\section{Potential of $\mathrm{CO}_{2}$ capture from flue gases by physicochemical and biological methods: a comparative study - Supporting Information}

Ismael Matito-Martos ${ }^{\mathrm{a}, \mathbb{f}}$, Claudia Sepulveda ${ }^{\mathrm{b}, \mathbb{f}, *}$, Cintia Gómez ${ }^{\mathrm{c}}$, Gabriel Acién ${ }^{\mathrm{c}}$, Julio

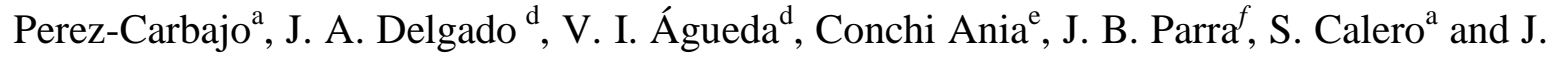
A. Anta ${ }^{\mathrm{a} *}$

II ${ }^{\mathrm{x}}$ these two authors contributed equally to this work.

${ }^{a}$ Department of Physical, Chemical and Natural Systems, University Pablo de Olavide, Sevilla 41013, Spain

${ }^{\mathrm{b}}$ Bio-innovation Centre, Antofagasta Institute, University of Antofagasta, Chile

${ }^{c}$ Department of Chemical Engineering, University of Almería, 04120 Almería, Spain

${ }^{d}$ Department of Chemical Engineering, Universidad Complutense de Madrid, 28040, Madrid, Spain

${ }^{e}$ CEMTHI (CNRS UPR 3079) Université d'Orléans, 45071, Orléans, France.

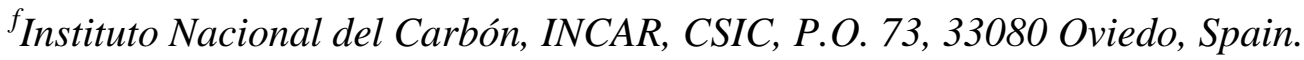

Corresponding authors*: Claudia Sepúlveda (laudia.sepulveda@uantof.cl), Juan A. anta (anta@upo.es)

\section{Section A. Details of interaction potentials for $\mathrm{CO}_{2}, \mathrm{~N}_{2}, \mathrm{O}_{2}$ and $\mathrm{H}_{2} \mathrm{O}$}

Atomic interactions were taken into account using electrostatic (Coulomb) and Van de Waals (Lennard-Jones) forces. For $\mathrm{CO}_{2}$, each interaction site corresponds to an atom center, with both partial charge and Lennard-Jones parameters assigned. ${ }^{1}$ Central dummy pseudo-atoms (D), with partial charges but without mass or Lennard-Jones parameters, are defined for $\mathrm{O}_{2}$ and $\mathrm{N}_{2}$ to reproduce their first non-zero electrostatic moment. ${ }^{2}$ The water molecule is described by the TIP5P/Ew model. ${ }^{3}$ This model has already been proved as suitable for studying adsorption of water in zeolites. ${ }^{4,5}$ This molecule is modeled by the $\mathrm{O}$ atom, the two $\mathrm{H}$ atoms and two extra dummy atoms (M) with tetrahedral site distribution, with the $\mathrm{O}$ at the center. There is only a single dispersive center at the $\mathrm{O}$, and point charges 
are located at the $\mathrm{H}$ and $\mathrm{M}$ sites, the latter accounting for the negative partial charge of the oxygen atom. ${ }^{3}$ Adsorbate-adsorbate cross van der Waals interactions are taken into account by Lorentz-Berthelot mixing rules. ${ }^{6}$ In the case of zeolites, every Si atom is surrounded by four $\mathrm{O}$ atoms, and so the latter dominate the dispersive forces. The adsorbate-framework interactions are defined by those of the framework $\mathrm{O}$ atoms with the atoms of the adsorbed molecules. Since zeolites not always obey the Lorentz-Berthelot mixing rules for the adsorbate-framework interactions, Lennard-Jones parameters need to be independently adjusted. ${ }^{1,7}$ To reproduce the interaction of $\mathrm{CO}_{2}, \mathrm{~N}_{2}$ and $\mathrm{O}_{2}$, and water with the zeolite, in this work we used parameters from Garcia-Sanchez et al., ${ }^{1}$ Martin-Calvo et al., ${ }^{8}$ and Castillo et al., ${ }^{9}$ respectively. The set of charges for the framework atoms was also taken from Garcia-Sanchez et al. ${ }^{1}$ All Lennard-Jones parameters and partial charges used in this work are collected in Table S1.

Table S1. Lennard-Jones parameters and partial charges of the adsorbates and the adsorbents

\begin{tabular}{ccccc}
\hline \multicolumn{1}{c}{ Atom 1 } & Atom 2 & $\varepsilon / k_{\mathrm{B}}(\mathrm{K})$ & $\sigma(\AA)$ & Charge $\left(\mathrm{e}^{-}\right)$ \\
\hline \multicolumn{4}{c}{ Adsorbed Molecules } \\
\hline $\mathrm{C}\left(\mathrm{CO}_{2}\right)$ & $\mathrm{C}\left(\mathrm{CO}_{2}\right)$ & 29.933 & 2.745 & 0.651 \\
$\mathrm{O}\left(\mathrm{CO}_{2}\right)$ & $\mathrm{O}\left(\mathrm{CO}_{2}\right)$ & 85.671 & 3.017 & -0.326 \\
$\mathrm{O}\left(\mathrm{O}_{2}\right)$ & $\mathrm{N}\left(\mathrm{O}_{2}\right)$ & 53.023 & 3.045 & -0.112 \\
$\mathrm{D}\left(\mathrm{O}_{2}\right)$ & $\mathrm{D}\left(\mathrm{O}_{2}\right)$ & - & - & 0.224 \\
$\mathrm{~N}\left(\mathrm{~N}_{2}\right)$ & $\mathrm{N}\left(\mathrm{N}_{2}\right)$ & 38.298 & 3.306 & -0.405 \\
$\mathrm{D}\left(\mathrm{N}_{2}\right)$ & $\mathrm{D}\left(\mathrm{N}_{2}\right)$ & - & - & 0.810 \\
$\mathrm{O}\left(\mathrm{H}_{2} \mathrm{O}\right)$ & $\mathrm{O}\left(\mathrm{H}_{2} \mathrm{O}\right)$ & 89.516 & 3.097 & - \\
$\mathrm{H}\left(\mathrm{H}_{2} \mathrm{O}\right)$ & $\mathrm{H}\left(\mathrm{H}_{2} \mathrm{O}\right)$ & - & - & 0.241 \\
$\mathrm{M}\left(\mathrm{H}_{2} \mathrm{O}\right)$ & $\mathrm{M}\left(\mathrm{H}_{2} \mathrm{O}\right)$ & - & - & -0.241 \\
$\mathrm{Zeolite}$ & & & & \\
\hline $\mathrm{O}(\mathrm{zeo})$ & $\mathrm{O}(\mathrm{zeo})$ & - & - & -0.393 \\
$\mathrm{Si}(\mathrm{zeo})^{\mathrm{Si}}(\mathrm{zeo})$ & - & - & 0.786 \\
$\mathrm{Adsorbed} \mathrm{Molecules}-\mathrm{Zeolite}$ & & \\
\hline $\mathrm{C}\left(\mathrm{CO}_{2}\right)$ & $\mathrm{O}(\mathrm{zeo})$ & 37.595 & 3.511 & - \\
$\mathrm{O}\left(\mathrm{CO}_{2}\right)$ & $\mathrm{O}(\mathrm{zeo})$ & 78.98 & 3.237 & - \\
$\mathrm{O}\left(\mathrm{O}_{2}\right)$ & $\mathrm{O}(\mathrm{zeo})$ & 60.189 & 3.129 & - \\
$\mathrm{D}\left(\mathrm{O}_{2}\right)$ & $\mathrm{O}(\mathrm{zeo})$ & - & - & - \\
$\mathrm{N}\left(\mathrm{N}_{2}\right)$ & $\mathrm{O}(\mathrm{zeo})$ & 60.580 & 3.261 & - \\
$\mathrm{D}\left(\mathrm{N}_{2}\right)$ & $\mathrm{O}(\mathrm{zeo})$ & - & - & - \\
$\mathrm{O}\left(\mathrm{H}_{2} \mathrm{O}\right)$ & $\mathrm{O}(\mathrm{zeo})$ & 13.710 & 3.377 & - \\
$\mathrm{H}\left(\mathrm{H}_{2} \mathrm{O}\right)$ & $\mathrm{O}(\mathrm{zeo})$ & - & - & - \\
$\mathrm{M}\left(\mathrm{H}_{2} \mathrm{O}\right)$ & $\mathrm{O}(\mathrm{zeo})$ & - & - & - \\
\hline
\end{tabular}




\section{Section B. Morphological and structural description of the zeolites}

BEA, MOR, FER, and MFI are zeolites with a structure consisting of interconnected channels with different directionality. Crystallographic positions of zeolite BEA were taken from Newsam et al. ${ }^{10}$ This structure has a 3-dimensional pore structure, with straight 12 membered-ring (MR) channels parallel to $x$ - and $y$-axes with pore limiting diameters around 6-7 $\AA$; and zig-zag $12 \mathrm{MR}$ pore path along the $z$-direction with a $5.6 \AA$ limiting diameter. Crystallographic positions of the atoms of zeolite MOR were taken from the work of Gramlich. ${ }^{11}$ This zeolite is formed by parallel channels in the $z$-axis, with $12 \mathrm{MR}$ windows; and additional adsorption sites in the $y$-axis, so called side pockets. Channels and pockets can be observed in the peaks in the Pore Size Distribution (PSD) in Fig. S1 at ca. 6 and 4.2 $\AA$ respectively. Pockets are accessible from the main channels only for small molecules. ${ }^{12}$ FER shows a 2-dimensional intersected system of channels of $4.7 \AA$ (10-membered rings along $z$-axis) and $3.4 \AA$ (8-membered rings along $y$-axis) limiting diameters. ${ }^{13} 10$-members rings also configure main channels of MFI zeolite ( $x$-axis), which are intersected by zig-zag secondary channels leading to a 3-dimensional system with limiting diameters around 4.5$4.7 \AA .{ }^{14}$ The two last zeolites under study, ITQ-29 and FAU, have cubic cells of 11.87 and 24.26 $\AA$, respectively. In this work we used crystallographic positions reported by Corma et al. (ITQ-29), ${ }^{15}$ and Hriljac et al. (FAU). ${ }^{16}$ Both zeolites show two types of interconnected cages (as can be seen from the two mains picks in the PSD in Fig S1). In FAU, the biggest cages ( $\alpha$-cages) are accessible through 12MR windows, with a limiting diameter of around $7.1 \AA$; while in ITQ-29, LTA-cages are accessible through an 8MR window, resulting on a lower limiting diameter (4.1 $\mathrm{A})$. For both structures, $\beta$-cages or sodalites are not accessible for most molecules due to the narrow windows that connect them with bigger cages (4- and 6-meber rings, respectively). 
Table S2 Structural and topological properties of the zeolites under study.

\begin{tabular}{|l|l|l|l|l|l|l|l|l|}
\hline Zeolite & $\begin{array}{l}\text { Pore } \\
\text { Volume } \\
\mathbf{( c m 3 g )}\end{array}$ & $\begin{array}{l}\text { Surface Area } \\
(\mathbf{m} \text { (2/g) }\end{array}$ & $\begin{array}{l}\text { Density } \\
\mathbf{( k g / m 3 )}\end{array}$ & $\begin{array}{l}\text { Channel } \\
\text { System }\end{array}$ & $\begin{array}{l}\text { Channel } \\
\text { Diameter }\end{array}$ & $\begin{array}{l}\text { Channel } \\
\text { Diameter }\end{array}$ & $\begin{array}{l}\text { Channel } \\
\text { Diameter }\end{array}$ & $\begin{array}{l}\text { Ring } \\
\text { sizes }\end{array}$ \\
\hline BEA & 0.277 & 984.93 & 1508.521 & $3 \mathrm{D}$ & 5.95 & 5.95 & 5.95 & 12654 \\
\hline FAU & 0.332 & 1020.88 & 1342.047 & $3 \mathrm{D}$-Cages & 7.35 & 7.35 & 7.35 & 1264 \\
\hline FER & 0.066 & 235.07 & 1837.870 & 2D (1D) & 4.69 & 3.4 & - & 10865 \\
\hline ITQ-29 & 0.286 & 849.28 & 1432.806 & 3D-Cages & 4.21 & 4.21 & 4.21 & 864 \\
\hline MOR & 0.150 & 477.92 & 1711.056 & 1D & 6.45 & - & - & 12854 \\
\hline MFI & 0.164 & 547.67 & 1796.342 & 3D & 4.7 & 4.46 & 4.46 & 10654 \\
\hline
\end{tabular}

BEA

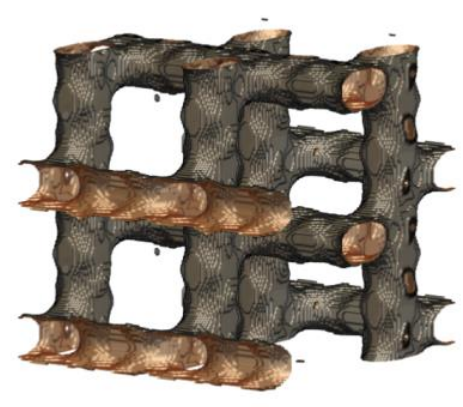

ITQ-29

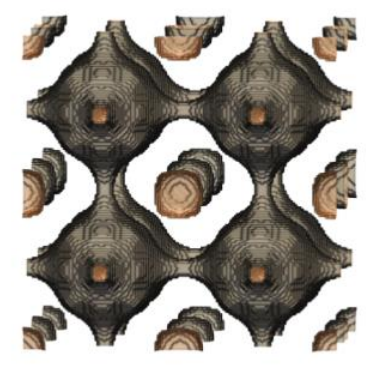

FAU
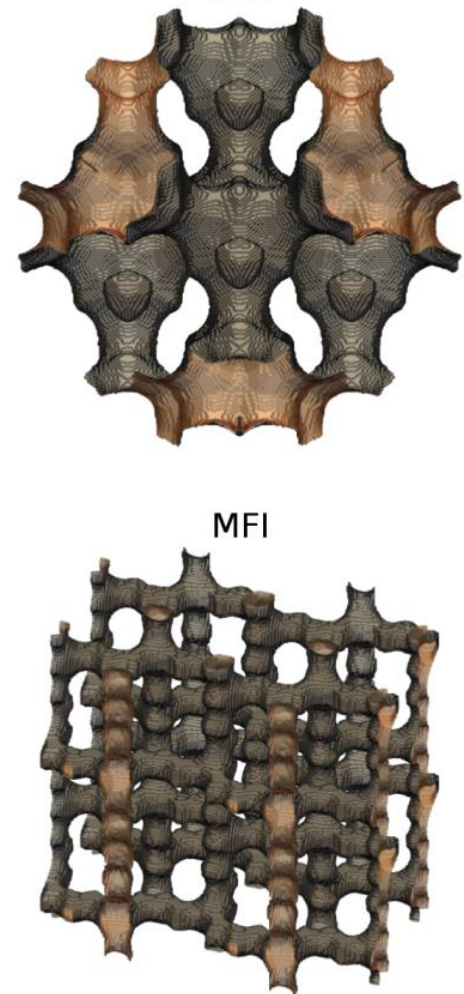

FER

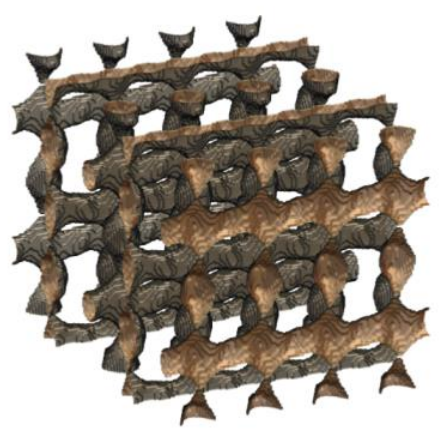

MOR

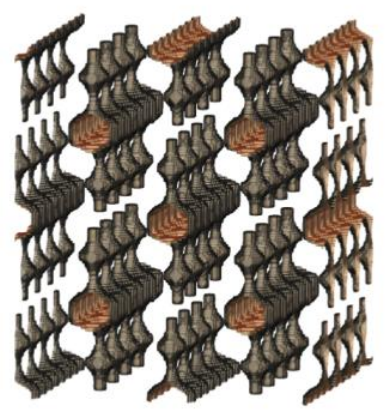

Figure S1. Energy grid surface of BEA, FAU, and FER zeolites (top) and ITQ-29, MFI and MOR zeolites (down). The accessible surface is colored in brown and the inaccessible surface in grey. 


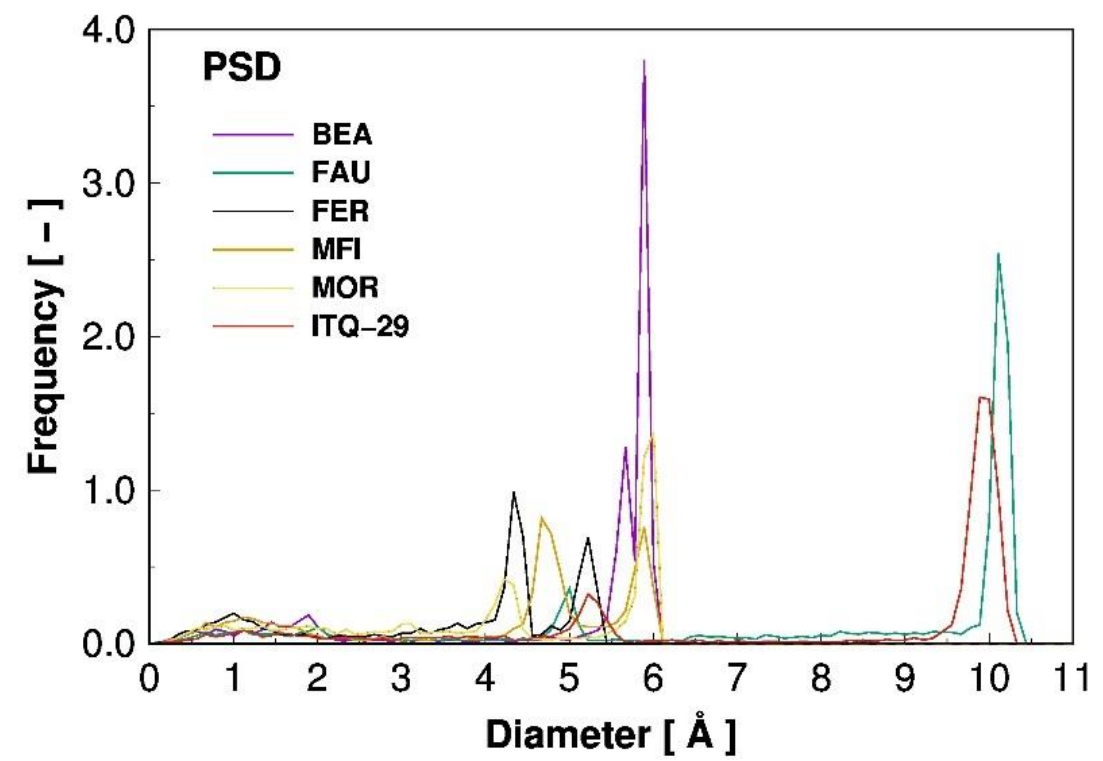

Fig. S2. Pore-size distributions of the zeolites under study. 


\section{Section C. Details of PSA simulations}

PSA simulations have been carried out with PSASIM software. ${ }^{17}$ Parameters of the simulation are collected in Table S3. PSA numerical simulations were performed using the cycle shown in Fig. S3 (adiabatic conditions) to discriminate between the separation performance of the different zeolites. Subsequently, a dual cycle (Figure S4) was used to improve the yield of $\mathrm{CO}_{2}$ zeolite for the MFI zeolite only.

The multicomponent adsorption isotherms for the PSA simulations were obtained by applying the IAST method to the pure component adsorption isotherms, previously obtained by GCMC simulations. Isotherms were fitted with the Langmuir model. A comparison between the pure component adsorption isotherms and the fitted ones is shown in Fig. S5. The fitted Langmuir parameters are shown in Table S4. A comparison between the multicomponent equilibrium data calculated with both methods is shown in Table S5. The introduction a correction factor for the adsorbed concentration of $\mathrm{CO}_{2}$ calculated from IAST method ranging between 0.93 and 1.02 was necessary to accurately predict multicomponent equilibrium data obtained from molecular simulation. The good agreement between the obtained results after applying the correction can be observed in the Table S5.

Table S3. Model parameters and operating conditions for PSA simulations.

\begin{tabular}{ll}
\hline Feed gas mixture & $\mathrm{N}_{2} / \mathrm{CO}_{2} / \mathrm{O}_{2} / \mathrm{H}_{2} \mathrm{O}$ \\
Feed composition, \%v/v & $75 / 10 / 11 / 3.2$ \\
Feed temperature, $\mathrm{K}$ & 298 \\
$\mathrm{P}_{\mathrm{H}}, \mathrm{P}_{\mathrm{L}}$, bar & $1,0.1$ \\
Feed gas velocity, $\mathrm{m} \mathrm{s}^{-1}$ & 0.2 \\
Purge superficial velocity, $\mathrm{m} \mathrm{s}^{-1}$ & 0.15 \\
Bed length, $\mathrm{m}$ & 1 \\
Bed radius, $\mathrm{m}$ & 0.1 \\
Bed porosity & 0.4 \\
Intraparticle porosity & 0.3 \\
${ }^{\text {a Particle density, kg m }}{ }^{-3}$ & crystal density*(1-intraparticle porosity) \\
Particle radius, $\mathrm{m}$ & $0.7 \cdot 10^{-3}$
\end{tabular}




\begin{tabular}{ll}
\hline Adsorbent heat capacity, $\mathrm{J} \mathrm{kg}^{-1} \mathrm{~K}^{-1}$ & 1000 \\
${ }^{\mathrm{b}}$ Molecular diffusivity, $\mathrm{m}^{2} \mathrm{~s}^{-1}$ & $1 \cdot 10^{-5}$ \\
Tortuosity & 3 \\
${ }^{\mathrm{b}} k_{g}, \mathrm{~J} \mathrm{~s}^{-1} \mathrm{~m}^{-1} \mathrm{~K}^{-1}$ & 0.06 \\
${ }^{\mathrm{b}} \mu, \mathrm{Pa} \mathrm{s}$ & $1.8 \cdot 10^{-5}$ \\
\hline $\begin{array}{l}{ }^{\mathrm{a}} \text { The following crystal densities have been employed }\left(\mathrm{kg} \mathrm{m}^{-3}\right) \text {. BEA: 1508; FAU: 1342; FER: 1838; ITQ-29: 1433; MFI: 1796; MOR: } \\
1711 .\end{array}$
\end{tabular}

Table S4. Fitted Langmuir parameters in the studied structures at $298 \mathrm{~K}$

\begin{tabular}{|c|c|c|}
\hline Gas/Structure & $K_{H}, \mathrm{~mol} \mathrm{~kg}^{-1} \mathbf{P a}^{-1}$ & $b, \mathbf{P a}^{-1}$ \\
\hline $\mathbf{N}_{2} /$ BEA & $1.693 \cdot 10^{-6}$ & $4.960 \cdot 10^{-7}$ \\
\hline $\mathrm{CO}_{2} / \mathrm{BEA}$ & $1.946 \cdot 10^{-5}$ & $3.679 \cdot 10^{-6}$ \\
\hline $\mathrm{O}_{2} / \mathbf{B E A}$ & $1.324 \cdot 10^{-6}$ & $2.873 \cdot 10^{-7}$ \\
\hline $\mathrm{H}_{2} \mathrm{O} / \mathrm{BEA}$ & $1.096 \cdot 10^{-7}$ & $2.193 \cdot 10^{-8}$ \\
\hline $\mathbf{N}_{2} / \mathbf{F A U}$ & $9.132 \cdot 10^{-7}$ & $1.338 \cdot 10^{-7}$ \\
\hline $\mathrm{CO}_{2} / \mathrm{FAU}$ & $4.844 \cdot 10^{-6}$ & $-1.006 \cdot 10^{-6}$ \\
\hline $\mathrm{O}_{2} / \mathrm{FAU}$ & $7.853 \cdot 10^{-7}$ & $5.259 \cdot 10^{-8}$ \\
\hline $\mathrm{H}_{2} \mathrm{O} / \mathrm{FAU}$ & $1.565 \cdot 10^{-7}$ & $1.565 \cdot 10^{-12}$ \\
\hline $\mathrm{N}_{2} /$ FER & $1.280 \cdot 10^{-6}$ & $1.004 \cdot 10^{-6}$ \\
\hline $\mathrm{CO}_{2} / \mathrm{FER}$ & $1.775 \cdot 10^{-5}$ & $1.559 \cdot 10^{-5}$ \\
\hline $\mathrm{O}_{2} /$ FER & $1.088 \cdot 10^{-6}$ & $7.494 \cdot 10^{-7}$ \\
\hline $\mathrm{H}_{2} \mathrm{O} / \mathrm{FER}$ & $3.972 \cdot 10^{-8}$ & $3.972 \cdot 10^{-8}$ \\
\hline $\mathrm{N}_{2} /$ ITQ-29 & $1.366 \cdot 10^{-6}$ & $2.882 \cdot 10^{-7}$ \\
\hline $\mathrm{CO}_{2} / \mathrm{ITQ-29}$ & $1.164 \cdot 10^{-5}$ & $1.018 \cdot 10^{-6}$ \\
\hline $\mathrm{O}_{2} /$ ITQ-29 & $1.146 \cdot 10^{-6}$ & $1.800 \cdot 10^{-7}$ \\
\hline $\mathrm{H}_{2} \mathrm{O} / \mathrm{ITQ}-29$ & $9.560 \cdot 10^{-8}$ & $9.560 \cdot 10^{-11}$ \\
\hline $\mathbf{N}_{2} /$ MFI & $2.730 \cdot 10^{-6}$ & $1.234 \cdot 10^{-6}$ \\
\hline $\mathrm{CO}_{2} / \mathrm{MFI}$ & $5.393 \cdot 10^{-5}$ & $1.982 \cdot 10^{-5}$ \\
\hline $\mathrm{O}_{2} / \mathrm{MFI}$ & $2.003 \cdot 10^{-6}$ & $7.387 \cdot 10^{-7}$ \\
\hline $\mathrm{H}_{2} \mathrm{O} / \mathrm{MFI}$ & $6.703 \cdot 10^{-8}$ & $2.234 \cdot 10^{-8}$ \\
\hline $\mathrm{N}_{2} / \mathrm{MOR}$ & $1.984 \cdot 10^{-6}$ & $7.214 \cdot 10^{-7}$ \\
\hline $\mathrm{CO}_{2} / \mathrm{MOR}$ & $1.226 \cdot 10^{-5}$ & $4.756 \cdot 10^{-6}$ \\
\hline $\mathrm{O}_{2} / \mathrm{MOR}$ & $1.573 \cdot 10^{-6}$ & $4.863 \cdot 10^{-7}$ \\
\hline $\mathrm{H}_{2} \mathrm{O} / \mathrm{MOR}$ & $1.058 \cdot 10^{-7}$ & $2.645 \cdot 10^{-8}$ \\
\hline
\end{tabular}

Table S5. Comparison between the multicomponent equilibrium data calculated from molecular simulation and IAST method.

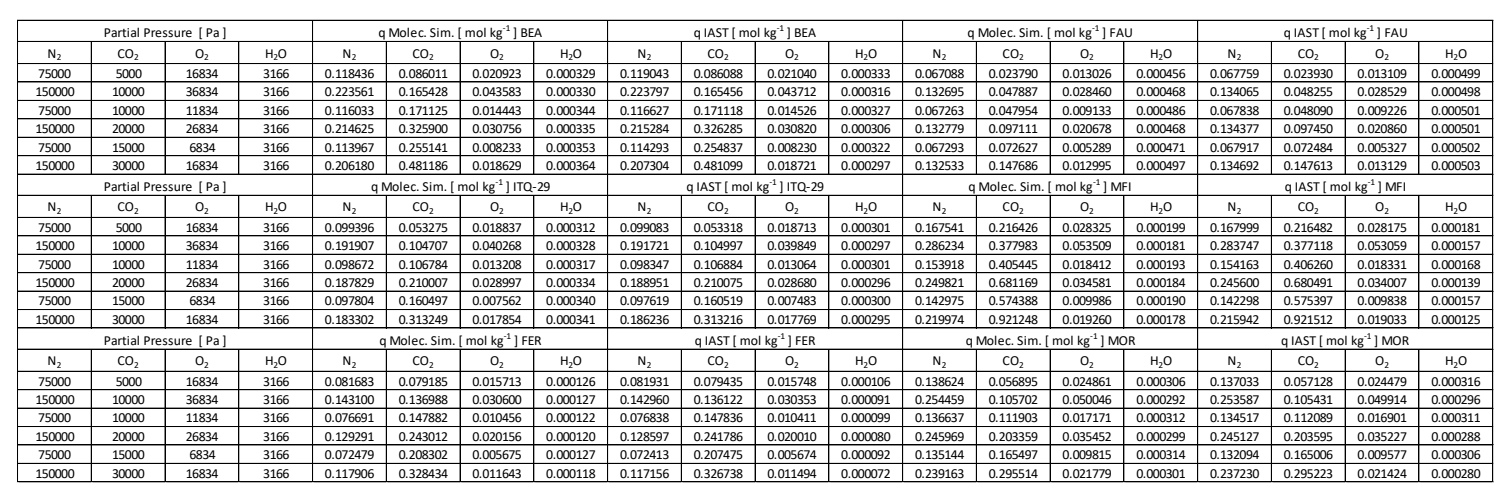


Table S6. Fitted Langmuir parameters in MFI structure.

\begin{tabular}{|l|l|}
\hline Parameter & Value \\
\hline$K_{H 0} \mathrm{~N}_{2}, \mathrm{~mol} \mathrm{~kg}^{-1} \mathrm{~Pa}^{-1}$ & $3.230 \cdot 10^{-9}$ \\
\hline$b_{0} \mathrm{~N}_{2}, \mathrm{~Pa}^{-1}$ & $1.330 \cdot 10^{-9}$ \\
\hline$-\Delta H \mathrm{~N}_{2}, \mathrm{~kJ} \mathrm{~mol}^{-1}$ & 16.65 \\
\hline$K_{H 0} \mathrm{CO}_{2}, \mathrm{~mol} \mathrm{~kg}^{-1} \mathrm{~Pa}^{-1}$ & $5.640 \cdot 10^{-10}$ \\
\hline$b_{0} \mathrm{CO}_{2}, \mathrm{~Pa}^{-1}$ & $2.000 \cdot 10^{-10}$ \\
\hline$-\Delta H \mathrm{CO}_{2}, \mathrm{~kJ} \mathrm{~mol}^{-1}$ & 28.32 \\
\hline$K_{H 0} \mathrm{O}_{2}, \mathrm{~mol} \mathrm{~kg}^{-1} \mathrm{~Pa}^{-1}$ & $3.914 \cdot 10^{-9}$ \\
\hline$b_{0} \mathrm{O}_{2}, \mathrm{~Pa}^{-1}$ & $1.515 \cdot 10^{-9}$ \\
\hline
\end{tabular}

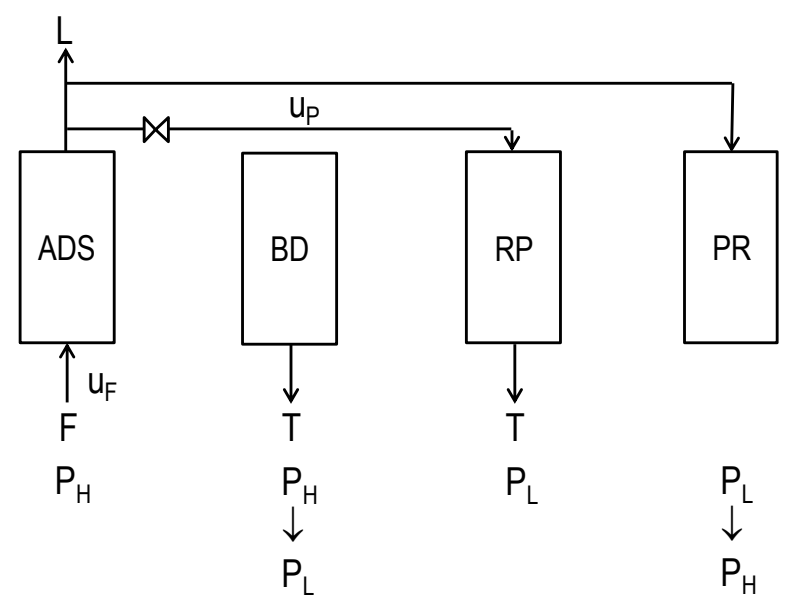

\begin{tabular}{|l|c|c|c|}
\hline Duration, s & 60 & 100 & 60 \\
\hline COLUMN I & ADS & BD & RP \\
\hline COLUMN II & RP & \multicolumn{1}{|c|}{$\mathrm{PR}$} & ADS \\
\hline \multirow{5}{*}{$-\Delta \mathrm{HO}_{2}, \mathrm{~kJ} \mathrm{~mol}^{-1}$} & 15.46 \\
\cline { 2 - 3 } & $K_{\mathrm{H} 0} \mathrm{H}_{2} \mathrm{O}, \mathrm{mol} \mathrm{kg}^{-1} \mathrm{~Pa}^{-1}$ & $3.621 \cdot 10^{-9}$ \\
\cline { 2 - 3 } & $b_{0} \mathrm{H}_{2} \mathrm{O}, \mathrm{Pa}^{-1}$ & $1.448 \cdot 10^{-9}$ \\
\hline$-\Delta H \mathrm{H}_{2} \mathrm{O}, \mathrm{kJ} \mathrm{mol}^{-1}$ & 7.25 \\
\hline
\end{tabular}

Figure S3. PSA cycle for comparing separation performance. $\mathrm{F}=$ feed gas, $\mathrm{L}=$ light product, $\mathrm{T}=$ tail gas, $\mathrm{PH}=$ high pressure, $\mathrm{PL}=$ low pressure, $\mathrm{ADS}=$ feed gas adsorption, $\mathrm{BD}=$ blowdown, $\mathrm{RP}=$ receive purge, $\mathrm{PR}=$ pressurization, $\mathrm{uF}=$ feed gas velocity in the adsorption step, $\mathrm{uP}=$ feed gas velocity in the purge step. 
a.

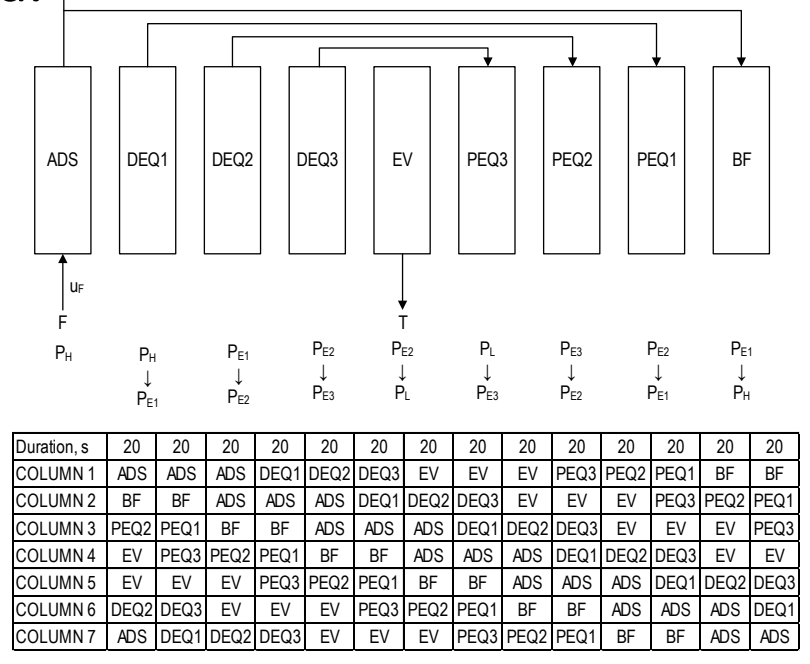

b.

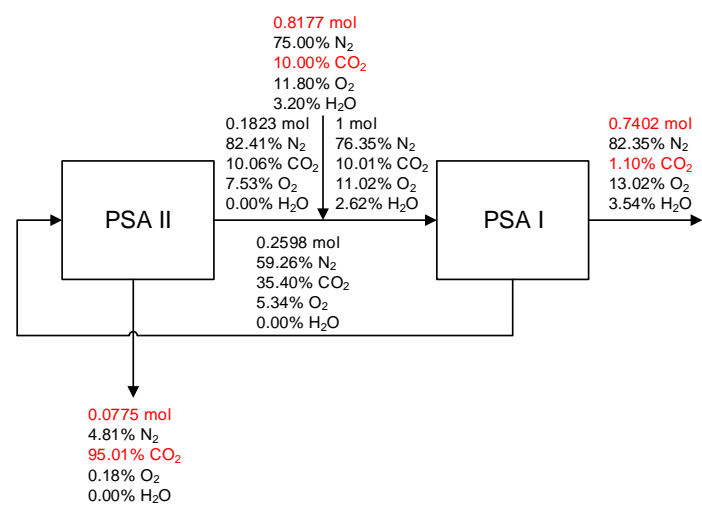

Figure S4. (a.) Individual PSA cycle in dual-PSA configuration for capturing $\mathrm{CO}_{2}$ from a $\mathrm{N}_{2} / \mathrm{CO}_{2} / \mathrm{O}_{2} / \mathrm{H}_{2} \mathrm{O}$ mixture. $\mathrm{F}=$ feed gas, $\mathrm{L}=$ light product, $\mathrm{T}=$ tail gas, $\mathrm{P}_{\mathrm{H}}=$ high pressure, $\mathrm{P}_{\mathrm{L}}=$ low pressure, $\mathrm{ADS}=$ feed gas adsorption, $\mathrm{DEQ} i=$ ith depressurizing equalization, $\mathrm{EV}=$ evacuation, $\mathrm{PEQ} i=$ ith pressurizing equalization, $\mathrm{BF}=$ backfill, $\mathrm{u}_{\mathrm{F}}=$ feed gas velocity in the adsorption step. (b.) Flowsheet of the dual-PSA cycle for capturing $\mathrm{CO} 2$ from a $\mathrm{N} 2 / \mathrm{CO} 2 / \mathrm{O} 2 / \mathrm{H} 2 \mathrm{O}$ mixture. PSA I is the rectifying cycle and PSA II is the stripping cycle. 

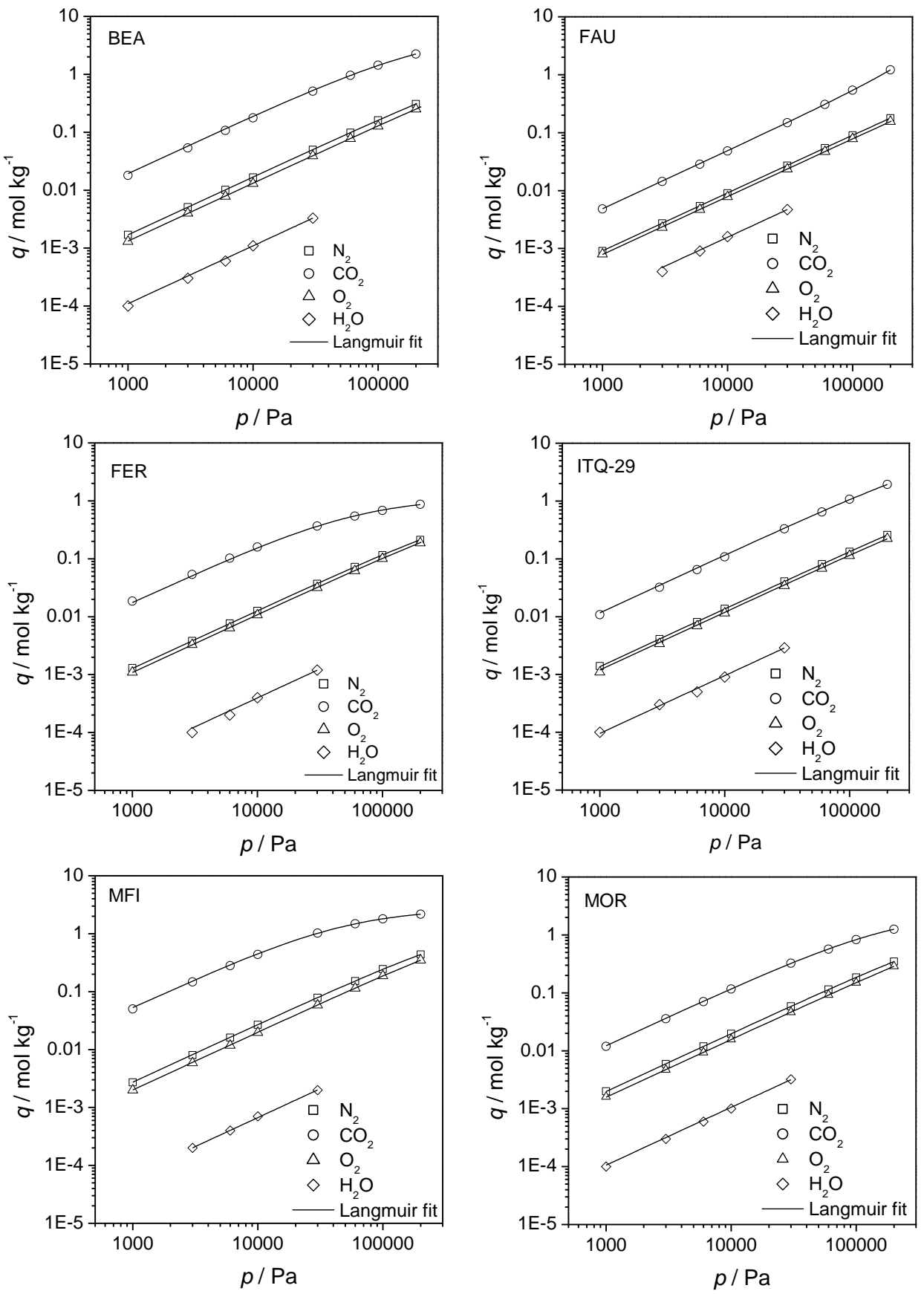

Figure S5. Comparison between pure adsorption isotherms at $298 \mathrm{~K}$ obtained by molecular simulation and fitted with Langmuir model. 

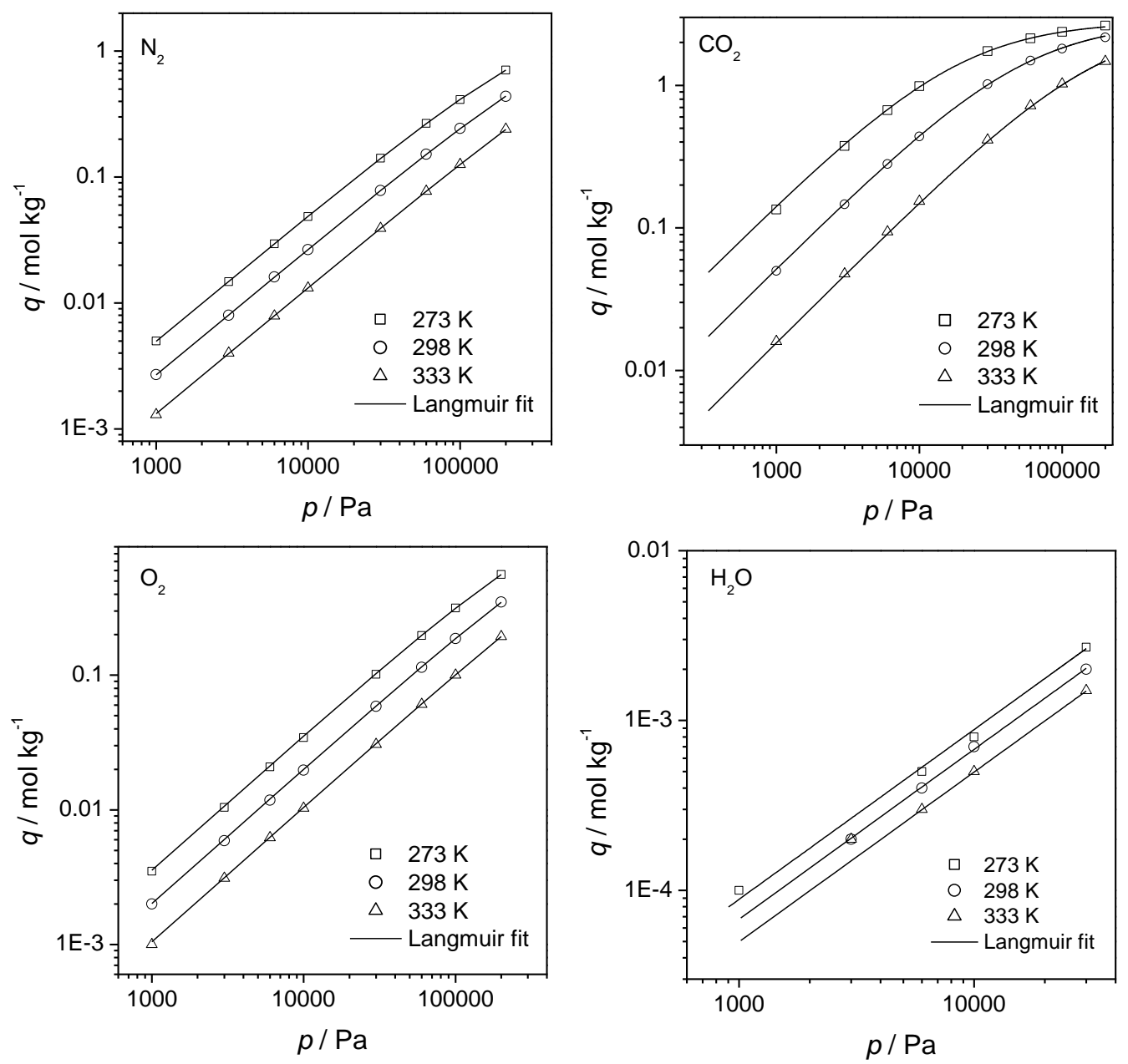

Figure S6. Comparison between pure adsorption isotherms in MFI structure obtained by molecular simulation and fitted with the temperature-dependent Langmuir model. 


\section{Section D. Microorganisms and culture media}

Table S7.- List of microorganisms selected, including microalgae and cyanobacteria, following the bibliographic revision.

\begin{tabular}{|l|l|l|}
\hline Species & Microalgae/cyanobacterium & Origin \\
\hline Scenedesmus almeriensis & Microalga & UAL collection \\
\hline Neochloris oleoabundans & Microalga & UAL collection \\
\hline Anabaena sp. & Cyanobacterium & CCAP 1403/13 \\
\hline Spirulina platensis & Cyanobacterium & UAL collection \\
\hline Nostoc commune & Cyanobacterium & CCAP 1453/33 \\
\hline Calothrix scytonemicola & Cyanobacterium & CCAP 1410/12 \\
\hline Scenedesmus dimorphis & Microalga & UAL collection \\
\hline Chlorella vulgaris & Microalga & CCAP 211/11D \\
\hline Monoraphidium griffithii & Microalga & CCAP 202/11D \\
\hline Synechococcus sp. & Cyanobacteria & CCAP 1479/9 \\
\hline
\end{tabular}

\section{Supplementary results}

Figure S7. Average occupation profiles for carbon dioxide (left) and nitrogen (right) in MOR zeolite at room temperature and 10 bar obtained from computed gas mixtures containing $\mathrm{CO}_{2}$ molar fractions of 0.05 (second file), 0.10 (third file), and 0.15 (fourth file). The figure shows the projection of the center of mass of the molecules over the $\mathrm{y}-\mathrm{z}$ plane. The color graduation indicates the occupation density (from black -null- to red -high-). To guide the view, a representation of the structure (first file) is added (oxygen atoms are depicted in red and silica atoms in yellow). A grid surface is also represented where the accessible part appears in blue while the non-accessible part is colored in gray. 
Figure S8. Average occupation profiles for carbon dioxide in MFI zeolite at room temperature and 1 bar (center-left), 2 bar (center-right), and 10 bar (right), obtained from computed gas mixture. The figures show the projection of the center of mass of the molecules over the z-x (top) and z-y (down) planes. The color graduation indicates the occupation density (from black to red). To guide the view a representation of the structure (first column) is added (oxygen atoms are depicted in red and silica atoms in yellow). A grid surface is also represented where the accessible part appears in blue while the non-accessible part is colored in gray.

Figure S9.- $\mathrm{CO}_{2}$ fixation rate $(\mathrm{A})$ and biochemical composition (B) of produced biomass of different strains tested at laboratory conditions. 


\section{References}

1 A. Garcia-Sanchez, C. O. Ania, J. B. Parra, D. Dubbeldam, T. J. H. Vlugt, R. Krishna and S. Calero, J. Phys. Chem. C, 2009, 113, 8814-8820.

2 A. Martin-Calvo, E. Garcia-Perez, A. Garcia-Sanchez, R. Bueno-Perez, S. Hamad and S. Calero, Phys. Chem. Chem. Phys., 2011, 13, 11165-11174.

3 S. W. Rick, J. Chem. Phys., 2004, 120, 6085-6093.

4 J. M. Castillo, D. Dubbeldam, T. J. H. Vlugt, B. Smit and S. Calero, Mol. Simul., 2009, 35, 1067-1076.

5 S. Calero and P. Gómez-Álvarez, RSC Adv., 2014, 4, 29571.

6 M. P. Allen and D. J. Tildesley, Computer Simulation of Liquids, Oxford Clarendon Press, Oxford, Second Edi., 2017.

7 R. Krishna, J. M. van Baten, E. Garcia-Perez and S. Calero, Ind. Eng. Chem. Res., 2007, 46, 2974-2986.

8 A. Martin-Calvo, J. J. Gutierrez-Sevillano, J. B. Parra, C. O. Ania, S. Calero, J. J. Gutiérrez-Sevillano, J. B. Parra, C. O. Ania and S. Calero, Phys Chem Chem Phys, 2015, 17, 24048-24055.

9 J. M. Castillo, J. Silvestre-Albero, F. Rodriguez-Reinoso, T. J. H. Vlugt and S. Calero, Phys. Chem. Chem. Phys., 2013, 15, 17374-17382.

10J. M. Newsam, M. M. J. Treacy, W. T. Koetsier and C. B. D. Gruyter, Proc. R. Soc. Math. Phys. Eng. Sci., 1988, 420, 375-405.

11V. Gramlich, Ph.D. Thesis, ETH, Zürich, Switzerland, 1971.

12E. Garcia-Perez, J. B. Parra, C. O. Ania, A. Garcia-Sanchez, J. M. Van Baten, R. Krishna, D. Dubbeldam and S. Calero, Adsorpt.-J. Int. Adsorpt. Soc., 2007, 13, 469-476.

13R. E. Morris, S. J. Weigel, N. J. Henson, L. M. Bull, M. T. Janicke, B. F. Chmelka and A. K. Cheetham, J. Am. Chem. Soc., 1994, 116, 11849-11855.

14H. van Koningsveld, H. van Bekkum and J. C. Jansen, Acta Crystallogr. Sect. B-Struct. Sci., 1987, 43, 127-132.

15 A. Corma, F. Rey, J. Rius, M. J. Sabater and S. Valencia, Nature, 2004, 431, 287-290.

16J. J. A. Hriljac, M. M. M. Eddy, A. K. K. Cheetham, J. A. A. Donohue and G. J. J. Ray, J. Solid State Chem., 1993, 106, 66-72.

17J. A. Delgado, V. I. Águeda, M. A. Uguina, P. Brea and C. A. Grande, Chem. Eng. J., 2017, 326, 117-129. 